\title{
HILGARDIA
}

A Journal of Agricultural Science Published by the California Agricultural Experiment Station

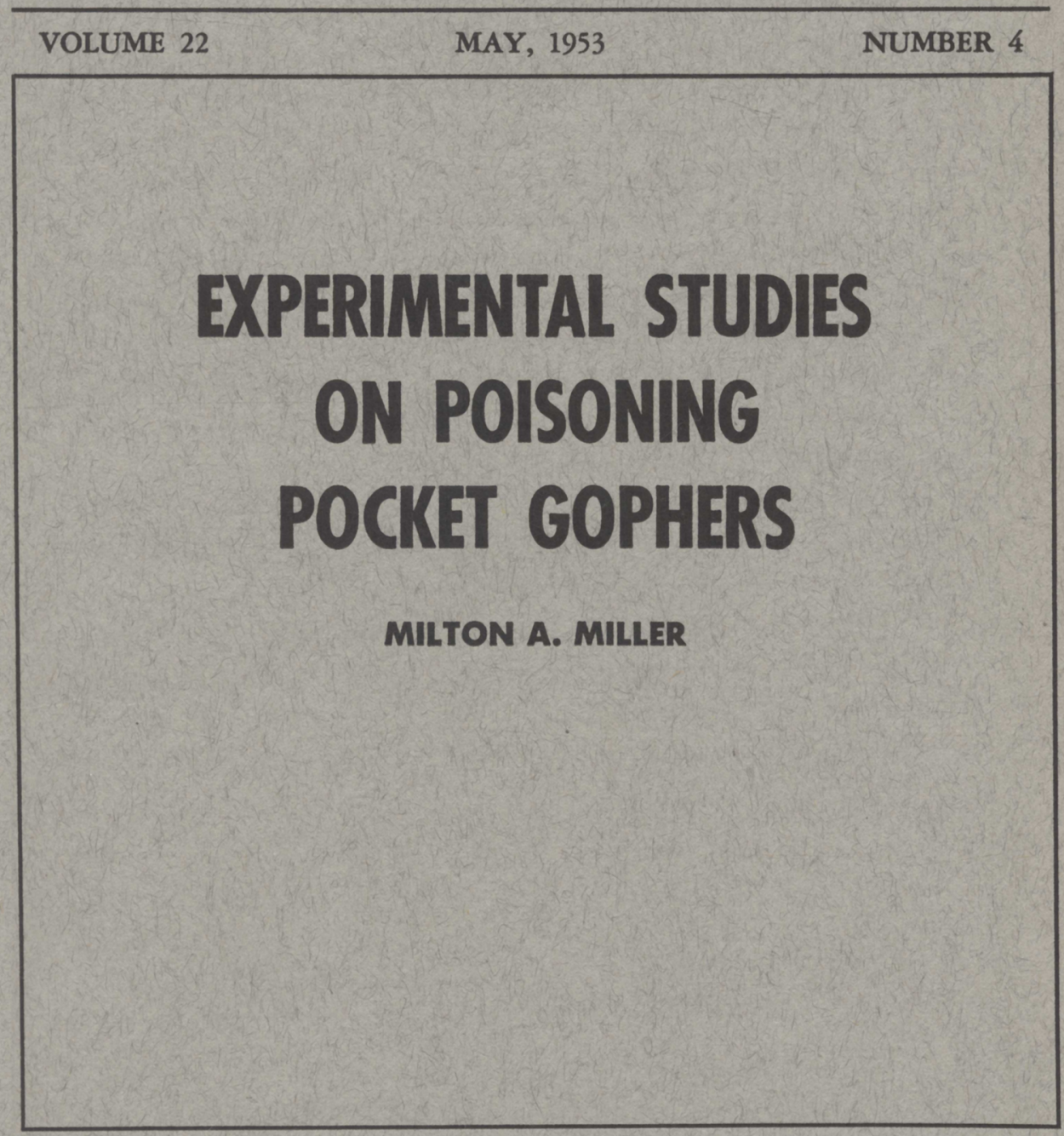

UNIVERSITY OF CALIFORNIA - BERKELEY, CALIFORNIA 
Field and laboratory tests on poisoning the Sacramento Valley pocket gopher (Thomomys bottae navus Merriam) are here reported. Nine poisons (including common and newly discovered rodenticides) and many kinds of bait materials were evaluated, graded dosages of the best poisons were bioassayed, and the effects of season of year, lures, and refrigeration on bait performance were tested.

Of the nine poisons field-tested on standard bait (mainly carrot), only Compound 1080, strychnine alkaloid, and strychnine sulfate gave practical kills; Castrix and thallium sulfate were moderately lethal; and zinc phosphide, ANTU, barium carbonate, and arsenic trioxide were relatively ineffective. Compound 1080 was far superior to strychnine, and the alkaloid form of strychnine proved better than the sulfate.

All three classes of bait materials tested-namely, root vegetables, grains, and fruits-were highly effective when poisoned with Compound 1080. With strychnine, root vegetables gave the best field-kills, fruits were significantly less effective, and grains gave poor results.

Recommendations based on these data and estimates of the cost of poisoning are given in the detailed summary of the paper. They will be useful to research workers, toxicologists, and rodent-control specialists, as well as to professional operators, agricultural commissioners, farm advisors, and farm managers. 


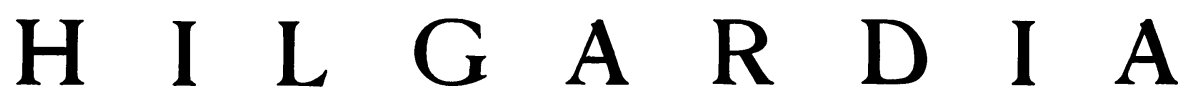

A Journal of Agricultural Science Published by

the California Agricultural Experiment Station

VoL. 22

MAY, 1953

No. 4

\section{EXPERIMENTAL STUDIES ON POISONING POCKET GOPHERS ${ }^{1}$}

\section{MILTON A. MILLER}

POCKET GOPHERS are important agricultural pests, particularly in the western United States, where man has not only encroached upon their natural habitat, but where he has, through cultivation and irrigation, augmented their food supply and improved conditions for their existence. As a consequence, damage by gophers to agriculture and other human enterprises totals many million dollars a year. A brisk trade in gopher traps and poison baits and the abundance of bulletins on gopher control (Storer and Mann, 1946 and 1948) attest their great economic importance.

In the long indictment against gophers, probably the most serious complaint is that their burrowing in earthen reservoirs, irrigation ditches, and levees causes costly and troublesome leakages. Another major charge is that they kill or drastically reduce the productive capacity of orchard trees and crop plants by gnawing on roots, live bark, shoots, crowns, bulbs, or other growing parts. They compete significantly with livestock for range forage (Fitch and Bentley, 1949) and cause deterioration or prevent improvement of mountain meadows in poor range condition (Moore and Reid, 1951). Their burrowing and mound building contribute to gully formation and soil erosion on hillsides and mountain slopes (Grinnell, 1923; Ellison, 1946). (That montane gophers through the centuries have helped erosive agencies create rich agricultural valleys and meadows at lower altitudes seems not to justify the depredations of gophers now dwelling in this ancestral alluvium.) Gophers spread weeds (Cook, 1939). They interfere with harvesting by producing large surface mounds that dull and clog the blades of mowing machines. Gopher mounds also smother considerable young vegetation (Buechner, 1942). They sometimes burrow into baled hay left standing in infested fields. ${ }^{3}$ On range and pasture, their easily collapsible tunnels and large surface mounds are an ever-present hazard to horse and rider and heavy livestock. Gophers damage airplane runways both by undermining and by throwing up large dirt piles, and they spoil golf greens and lawns in similar fashion.

\footnotetext{
${ }^{1}$ Received for publication October 31, 1952.

${ }^{2}$ Associate Professor of Zoölogy and Associate Zoölogist in the Experiment Station, Davis.

${ }^{3}$ Unpublished observations.
} 
Their tunnels provide shelter and runways for white-footed mice (Peromyscus), which eat the seeds of yellow pine, causing failure of reproduction of pine forests; and the gophers themselves, although rejecting pine seeds, probably damage pine trees by gnawing the roots and bark (Moore, 1943). They aid subterranean termites and decay fungi in gaining access to wooden structures by piling excavated dirt against protective concrete foundations (Thomas, 1951). They gnaw on underground electric cables causing expensive breakdowns and delays, and much time and money have been spent in devising gopher-proof cables for use in infested areas (Howard, 1953). Gophers seemingly do as much damage indirectly by their incessant gnawing and burrowing as by direct feeding on crops-if not more; and the total loss chargeable to these rodents is enormous.

Poisoning, properly done, is an effective method for eradicating pocket gophers and other rodent pests, especially where large-scale control is needed. Despite the many publications dealing with gopher control, however, critical data on the efficiency of various methods are scanty. Precise information is lacking on the effectiveness of poison baits under actual operating conditions. Furthermore, few or no field data are available on the susceptibility of gophers to baits poisoned with recently discovered rodenticides such as Compound 1080 or sodium fluoroacetate (Kalmbach, 1945), ANTU or alphanaphthylthiourea (Richter, 1945), Castrix or 2-chloro-4-dimethylamino-6methylpyrimidine (a wartime German discovery), and zinc phosphide. These new poisons were developed during and since World War II, when research on rodenticides, particularly the search for new and better rat poisons, was greatly accelerated because of (1) critical shortages of such standard toxicants as strychnine, thallium, and squill; (2) the increased menace of plague and other rodent-borne diseases; and (3) the need for more effective control of pests that deplete or spoil food supplies and damage farm installations.

In view of these deficiencies a comprehensive study of poison baits for pocket gophers was initiated in 1944 at the College of Agriculture, University of California at Davis, as an important part of a research project on biology and control of the pocket gopher. A preliminary report on the poisoning investigations (Miller, 1950) and a paper on size of baits (Miller and Howard, 1951) have been published. The present article summarizes a major part of the investigation under the following headings: (1) poisons, (2) bait materials, (3) practical field dosages, (4) seasonal effects and related factors, (5) lures, (6) bait storage, and (7) cost of poisoning.

\section{METHODS General Considerations}

The effectiveness of poison baits for pocket gophers can readily be determined in the field by the "open-hole test." This is based on two traits of gophers: (1) an instinct to plug, in a relatively short time, any opening made into their burrows; and (2) a remarkably solitary disposition, as only one gopher normally inhabits a burrow system.

The test procedure involves three steps in chronological order as follows: (1) placing the baits, (2) determining bait acceptance, and (3) estimating 
kill. On the first day, bait is injected (by methods later described) into the gopher's burrow. After an appropriate period (generally a day or two afterwards), each bait site is carefully dug open to determine if a runway was hit, and if so how much of the proffered bait was taken. The next day, excavated bait sites are re-examined to determine whether or not exposed tunnels are plugged. If these remain open, it can be assumed that the burrow occupant was killed by the bait (provided, of course, that bait was taken); but if any tunnels are plugged, the gopher is presumed to be alive. Occasionally a dead gopher is found at the bait site as direct evidence of kill.

Abandoned burrows constitute an exception to the rule that absence of plugging indicates a kill. These are easily detected as burrow systems from which no bait is taken, and yet the excavated sites remain open. Such systems are infrequently encountered and are excluded in analysis of acceptance and kill. As will be demonstrated, the percentage of inhabited burrow systems that show open bait sites after treatment is a reliable index of the effectiveness of the bait.

As nontoxic controls, clean baits are frequently tested along with poisoned baits to check on natural mortality or dispersal during the course of experiments. So rarely are open bait sites found where clean bait has been taken (only in about 2-3 per cent of control burrows) that this source of error is negligible and may be disregarded.

The open-hole test has certain limitations. First, on point of acceptance, it is virtually impossible to ascertain what happens to bait removed by the gopher from a bait site. It may be eaten, carried away and cached, or disposed of in other ways. Secondly, it gives no information on cumulative poisoning or sublethal effects, which may result in reduced viability and even death of the gopher after the test is concluded. Some allowance for slow-acting poisons can be made, however, by extending the period between injection of baits and opening of bait sites.

A more serious fault is that the test assumes only one gopher per burrow system. At times, however, more than one gopher may occupy a system, as perhaps male and female in breeding season or females with litters. Hence, as Horn (1923) points out, "- -should one or more pocket gophers be killed, there may be others left to close the opening made into the run, thus seeming to indicate that no kill has been made-." It is also possible that all of the several gophers occupying a burrow system might be killed, yet only one kill would be recorded. Again, unbeknown to the operator, another gopher might invade a burrow after the death of the original occupant and plug open bait sites before the final observation, so that no kill would be recorded even though one was made.

On all these counts, any mortality estimate based on percentages of burrows remaining open is apt to be somewhat lower than the actual kill obtained. Such percentages, therefore, represent minimal or conservative estimates of mortality and should not be taken as absolute. This limitation does not invalidate the open-hole test, as Horn implies, but rather makes it more conservative.

Several ways of circumventing this difficulty have been suggested: (1) conduct bait-efficiency tests out of breeding season when few, if any, bur- 
rows would house more than one gopher; (2) adjust kill percentages statistically according to the incidence of plural occupancy at the time of testing; and (3) evaluate poison baits on a relative rather than an absolute basis. The first suggestion was out of the question because it was known from a previous study (Miller, 1946) that, in irrigated alfalfa fields wherein most of the testing was done, gophers breed throughout the year, autumn being the only low reproductive period. As will be shown, limitation of testing to this one season was neither feasible nor necessary.

Statistical adjustment of mortality estimates is theoretically possible provided (1) the percentage of burrows occupied by more than one gopher during the test period and (2) the toxicity of the poison are known, since any correction would be a function of both these variables. Estimates of the incidence of plural occupancy are hard to find, but a rough approximation might be made from the percentage of suckling females in the gopher population. This would indicate the relative frequency of burrows with litters, presumably the most common type of plural occupancy. A year's trap collection of more than a thousand gophers from irrigated alfalfa fields (Miller, 1946) shows that females with fresh placental scars and lactating mammae averaged per month as follows: spring and summer, 14 per cent; fall, 6 per cent; and winter, 12 per cent. These values are probably of the right order of magnitude to serve as correction factors, since the best baits average between 80 and 90 per cent apparent kill. Thus, a poison-bait formula that shows 90 per cent open bait sites in field tests conducted during spring, summer, or winter might actually be giving practically complete kills of gophers taking the baits in those seasons. During autumn, when the incidence of plural occupancy is probably lowest, the same poison bait would theoretically be expected to give a somewhat higher percentage of open bait sites.

Statistical adjustment of apparent kill percentages does not seem feasible since (1) it is obviously very difficult to obtain an accurate estimate of the incidence of plural occupancy, (2) the correction involved is relatively small, (3) there are no significant seasonal differences in apparent kill with the same bait (see later), and (4) there are better ways of circumventing the difficulty.

For practical purposes, the best way of dealing with the problem of plural occupancy is to evaluate poison baits on a relative rather than an absolute basis. This involves comparison of performance between one or more experimental baits and a standard or toxic-control formulation tested concurrently or under nearly identical conditions. Such a procedure cancels the effect of extraneous variables, including plural occupancy, provided enough burrows are treated with each formulation. Any new bait (or treatment) can be then rated as equal to, better than, or poorer than the standard, or compared with any other formulation so rated.

The open-hole test has certain distinct advantages over other methods of evaluating poison baits for gophers, primarily because it gives quantitative data on acceptance and toxicity of baits under natural field conditions. Another field method, sometimes used to determine bait performance, is to smooth off the tops of all existing mounds or sprinkle them with powder at the time of treatment, so that any fresh mounds (indicating gophers still living) 
can be easily observed when the poisoned area is revisited. Rains immediately following treatment also serve to smooth down gopher mounds so that fresh diggings are more readily seen. This alternative method gives a rough check but is time-consuming, gives no information on bait acceptance, and does not indicate whether the treated burrows are inhabited or vacant. It is much less precise than the open-hole test since new mounds may be overlooked, especially if they are small and the vegetation is high, and there are seasonal fluctuations in the rate of burrowing. Any attempt to determine the kill by excavating treated burrow systems to find dead gophers is so laborious as to be utterly impractical.

Laboratory tests in which poisons are administered to captive animals by injection, by stomach tube, or even on food yield much valuable toxicological information, but such tests are more or less artificial. They are useful in preliminary screening of poisons, in establishing lethal dosages, in determining bait acceptance and preferences, and in supplementing the field tests in other ways. The final answer on the effectiveness of a poison bait, however, is its actual performance in the field, which can best be determined by the open-hole test.

\section{Preparing Baits}

Several kinds of root vegetables, grains, and dried fruits were used in these studies for bait. Vegetables were cut with a cork borer into cylindrical pieces, each measuring about $5 / 8$ inch in diameter by $1 \frac{1 / 4}{4}$ inches in length and weighing from 6 to 7 grams. Grains and raisins were put up in 7 -gram packets. Dried fruits (except raisins and prunes) were cut and rolled into cylinders roughly equivalent in size and weight to the vegetable baits. Prunes were slit lengthwise, and measured amounts of poison were inserted into the cut.

The poisons were either dusted evenly over the baits or dissolved and sprinkled over them so that each piece of bait received an equal share. For uniform distribution, the poison was added, a little at a time, to the baits, which were shaken and rolled in mixing jars between dustings. When small dosages were used, bait pieces were usually dipped individually into measured amounts of poison, or an equal number of drops of a solution of the poison was placed on each piece of bait. Before dusting, grain baits were coated with a film of mineral oil to make the poison adhere better. Graded dosages of poison were used on several of the baits so that dosage-mortality curves could be computed.

\section{Setting Baits}

For locating gopher runs, the small end of a probe (fig. 1) was thrust repeatedly into the ground near fresh gopher mounds until it hit a tunnel. An abrupt, readily detectable drop of the probe as its point passed from the resistant soil into and through an open tunnel signaled the hit. After a runway was thus located, the probe hole was enlarged for insertion of bait by reaming it with the handle end of the probe. Cut vegetable baits were dropped into runways through probe holes, while smaller baits like grain and raisins were poured in through a funnel. As standard procedure, two 
pieces of the vegetable or fruit baits, or two packets of the grain or raisin baits, were inserted into each burrow system, usually through separate probe holes. The probe holes were then plugged with cotton, and the bait sites were marked with numbered stakes for convenience in relocating them and in recording results. The amount of bait offered each gopher was recorded.

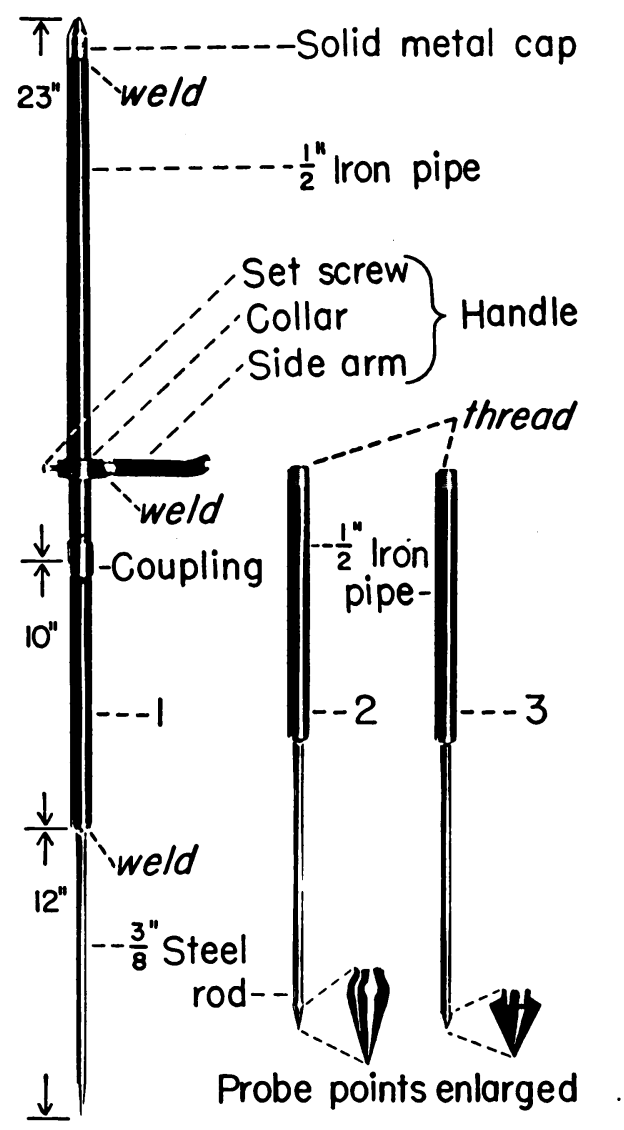

Fig. 1. Probe for locating gopher tunnels. To the upper section of the shaft may be coupled any one of the three lower sections (1-3), the points of which are designed for probing in different kinds of soil. (1) sharp tapering point for heavy, hard, or dry soil; (2) carrot-shaped point for average moist soil; (3) blunt, broad tip for loose, sandy, or wet soil (Photo by Margery P. Mann).

\section{Determining Acceptance}

Bait sites were carefully dug open a day or two after baits were placed. When slow-acting poisons were used, an interval of three or four days was allowed between placing the baits and opening the sites. The amount of bait taken from each bait site was recorded. Any bait recovered at this time was removed. Acceptance percentages were calculated by dividing the amount of bait taken by the amount offered. 


\section{Estimating Kill}

A day or two after the bait sites were opened, they were revisited to determine mortality, as judged by the presence or absence of plugging. This observation should not be made too soon after opening bait sites, as the gopher must be given ample time to plug the openings if able to do so. Nontoxic bait sites were usually plugged soon after they were opened, frequently within an hour; this indicates that a day certainly gives ample time for plugging.

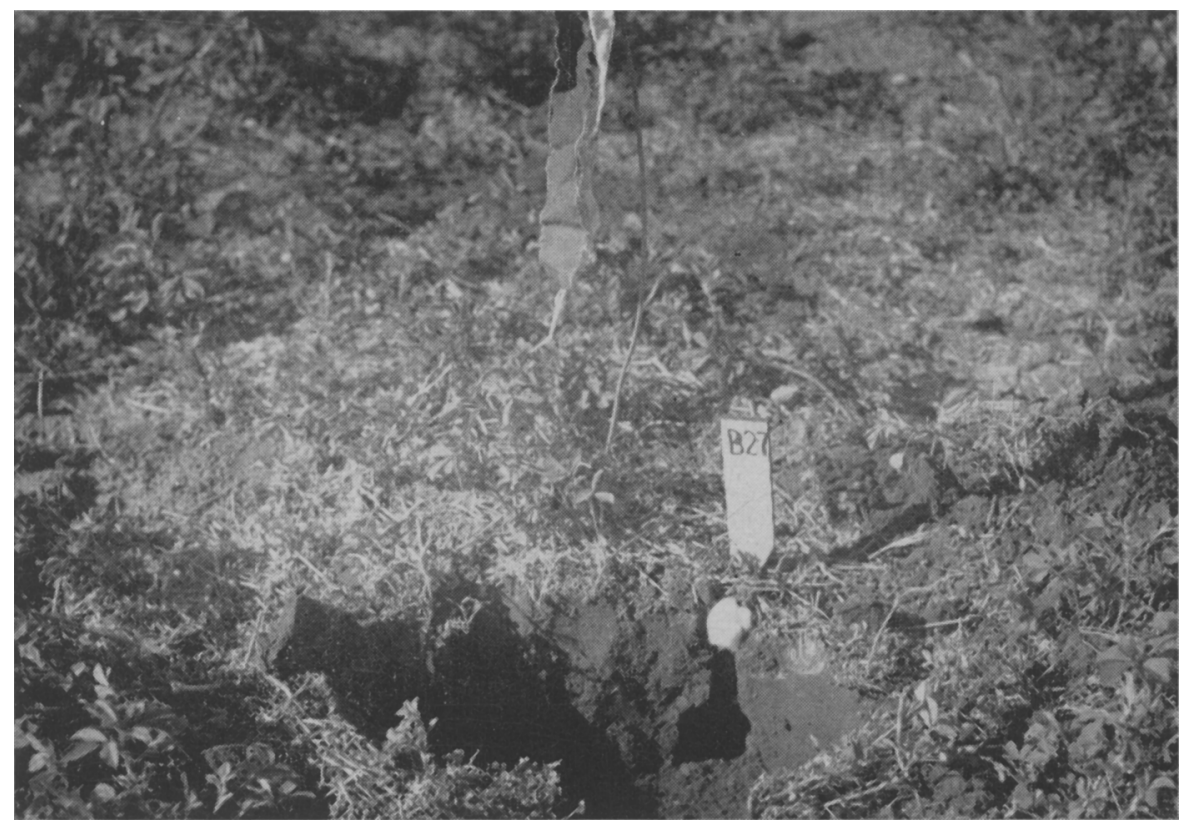

Fig. 2. Excavated bait site (foreground) showing a cross section of an open gopher tunnel with a probe hole (plugged with cotton) entering its roof. A numbered stake and a cloth flag on a long wire mark the site. Poison bait dropped into the tunnel through the probe hole yesterday has been taken by the gopher. If tomorrow the tunnel is found open (as now), it will be presumed that the burrow occupant was killed, since a living gopher will invariably plug the opening and sometimes even fill the entire excavation with dirt (Photo by W. E. Howard).

On the other hand, the final observation of bait sites should not be made too long after their excavation because the delay might give another gopher opportunity to move into a burrow after the death of the original occupant and to plug the opening.

As previously stated, the percentage of open systems is an index of kill, but this may be computed on two different bases depending on the kind of information desired. For practical purposes what is desired is the relation of "dosage administered" to kill-that is, a kill percentage which involves acceptance as well as toxicity of the bait. Such percentages may be computed by dividing the number of systems remaining open, after treatment with a 
specified amount of poison bait $(n)$, by the total number of inhabited systems successfully baited $(N)$. Since the denominator includes all occupied systems baited regardless of the amount of bait taken, it is clear that this percentage is a function both of acceptance and toxicity, and hence it represents the over-all operational efficiency of the bait. Hereafter called "fieldkill," this percentage and its standard error may be calculated according to the formula:

$$
\text { Field-kill per cent } \pm \text { S.E. }=100\left[\frac{n}{N} \pm \sqrt{\frac{p(1-p)}{N}}\right]
$$

where $p=n / N$, the field-kill percentage, expressed as a decimal.

Mortality may also be estimated on the basis of the amount of bait actually taken, to eliminate the acceptance factor. Such kill percentages may be calculated by dividing the number of systems remaining open after a certain amount of bait was accepted by the total number of systems wherein that amount was accepted. Kill percentages calculated on the basis of amount of bait actually known to be taken are frequently higher than field-kill percentages based on the amount of bait offered regardless of acceptance.

\section{RESULTS AND DISCUSSION}

\section{Poisons}

To determine their relative efficiencies in killing pocket gophers, eight different poisons were field-tested on various baits. The poisons tested were ANTU, arsenic trioxide $\left(\mathrm{As}_{2} \mathrm{O}_{3}\right)$, barium carbonate $\left(\mathrm{BaCO}_{3}\right)$, Castrix, Compound 1080, strychnine (alkaloid and sulfate), thallium sulfate $\left(\mathrm{Tl}_{2} \mathrm{SO}_{4}\right)$, and zinc phosphide $\left(\mathrm{Zn}_{3} \mathrm{P}_{2}\right)$. Results are given in tables 1 to 4 . For comparing poisons, data obtained with carrots will be used since all poisons were tried first on this well-accepted bait and some were tested only on carrots. Other bait materials will be considered in the next section of this report.

Bait acceptance (per cent of bait taken by gophers from placement sites) was high and practically the same for all poisoned-carrot baits, ranging between 83 and 100 per cent of baits taken, with an average of about 93 per cent as compared to a 96 per cent average acceptance of nontoxic carrots. Average acceptances of other root vegetables, fruits, or grain baits were practically the same as for carrots regardless of the poison used. The average acceptance for toxic baits in general (about 91 per cent) was about 6 per cent less than for nontoxic controls, indicating that poisons may have a slightly repellent action, especially at higher dosages (see below). A part of the difference, however, may be attributed to death of gophers before they can remove all the bait from the placement sites.

An alternate analysis of acceptance showed that all bait was taken on the average in 86 per cent of burrows treated with poison baits, as compared with 92 per cent when nontoxic baits were used. The range for complete acceptance of toxic carrot baits was between 74 and 100 per cent of burrows baited. In a small percentage of inhabited burrows, none of the proferred bait was taken, especially when heavy dosages of poison were applied. With strychnine alkaloid, for example, the percentage of complete refusal rose 
TABLE 1

FIELD TESTS WITH NINE POISONS ON VARIOUS ROOT-VEGETABLE BAITS

\begin{tabular}{|c|c|c|c|c|c|}
\hline \multirow{2}{*}{ Poison-bait } & \multicolumn{2}{|c|}{ Dosage } & \multirow{2}{*}{$\begin{array}{c}\text { Number } \\
\text { of burrows } \\
\text { baited }\end{array}$} & \multirow{2}{*}{$\begin{array}{l}\text { Acceptance, } \\
\text { per cent of } \\
\text { bait taken }\end{array}$} & \multirow{2}{*}{$\begin{array}{l}\text { Kill, per } \\
\text { cent of open } \\
\text { sites } \pm \text { S.E. }\end{array}$} \\
\hline & $\begin{array}{c}\text { Mg poison } \\
\text { per burrow }\end{array}$ & $\begin{array}{l}\text { Poison : Bait } \\
\text { ratio by wt. }\end{array}$ & & & \\
\hline Strychnine alkaloid-carrot... & $\begin{array}{r}100 \\
100 \\
80 \\
50 \\
40 \\
40 \\
25 \\
20 \\
10 \\
5 \\
2\end{array}$ & $\begin{array}{l}1: 140 \\
1: 280 \\
1: 350 \\
1: 280 \\
1: 350 \\
1: 700 \\
1: 560 \\
1: 700 \\
1: 1,400 \\
1: 2,800 \\
1: 7,000\end{array}$ & $\begin{array}{r}52 \\
9 \\
21 \\
160 \\
52 \\
8 \\
18 \\
55 \\
18 \\
17 \\
9\end{array}$ & $\begin{array}{r}83 \\
82 \\
93 \\
92 \\
91 \\
91 \\
92 \\
96 \\
92 \\
91 \\
100\end{array}$ & $\begin{array}{c}65 \pm 6.8 \\
100 \\
86 \pm 7.6 \\
80 \pm 3.1 \\
73 \pm 6.1 \\
75 \pm 10 \\
56 \pm 12 \\
67 \pm 6.3 \\
56 \pm 12 \\
47 \pm 12 \\
\quad 0\end{array}$ \\
\hline Strychnine alkaloid-sweet potato..... & $\begin{array}{l}80 \\
80 \\
50 \\
40 \\
40 \\
20\end{array}$ & $\begin{array}{l}1: 123 \\
1: 360 \\
1: 280 \\
1: 360 \\
1: 700 \\
1: 700\end{array}$ & $\begin{array}{r}8 \\
26 \\
20 \\
14 \\
14 \\
29\end{array}$ & $\begin{array}{l}88 \\
85 \\
85 \\
93 \\
86 \\
95\end{array}$ & $\begin{array}{l}88 \pm 11 \\
73 \pm 8.7 \\
80 \pm 8.9 \\
71 \pm 12 \\
57 \pm 13 \\
66 \pm 8.7\end{array}$ \\
\hline Strychnine alkaloid-Irish potato $\ldots \ldots \ldots \ldots$ & $\begin{array}{l}50 \\
40 \\
20\end{array}$ & $\begin{array}{l}1: 280 \\
1: 360 \\
1: 700\end{array}$ & $\begin{array}{l}28 \\
22 \\
21\end{array}$ & $\begin{array}{l}96 \\
86 \\
93\end{array}$ & $\begin{array}{l}61 \pm 9.2 \\
64 \pm 10 \\
86 \pm 7.6\end{array}$ \\
\hline Strychnine alkaloid-turnip $\ldots \ldots \ldots \ldots \ldots$ & $\begin{array}{l}50 \\
20\end{array}$ & $\begin{array}{l}1: 232 \\
1: 560\end{array}$ & $\begin{array}{l}28 \\
21\end{array}$ & $\begin{array}{l}68 \\
95\end{array}$ & $\begin{array}{l}32 \pm 8.8 \\
71 \pm 9.9\end{array}$ \\
\hline Strychnine alkaloid-beet.... & $\begin{array}{l}50 \\
40\end{array}$ & $\begin{array}{l}1: 280 \\
1: 360\end{array}$ & $\begin{array}{l}25 \\
11\end{array}$ & $\begin{array}{l}90 \\
86\end{array}$ & $\begin{array}{l}72 \pm 8.9 \\
91 \pm 8.6\end{array}$ \\
\hline Strychnine alkaloid-sugar beet......... & 50 & $1: 280$ & 37 & 93 & $70 \pm 7.5$ \\
\hline Strychnine sulfate-carrot. . & $\begin{array}{l}80 \\
50 \\
40 \\
25 \\
20 \\
10\end{array}$ & $\begin{array}{l}1: 175 \\
1: 280 \\
1: 350 \\
1: 560 \\
1: 700 \\
1: 1,400\end{array}$ & $\begin{array}{l}41 \\
56 \\
28 \\
15 \\
33 \\
13\end{array}$ & $\begin{array}{r}95 \\
93 \\
96 \\
88 \\
95 \\
100\end{array}$ & $\begin{array}{l}63 \pm 7.5 \\
77 \pm 5.6 \\
61 \pm 9.2 \\
53 \pm 13 \\
61 \pm 8.4 \\
23 \pm 12\end{array}$ \\
\hline ANTU-carrot............... & $\begin{array}{r}160 \\
80 \\
40 \\
20\end{array}$ & $\begin{aligned} 1: 90 \\
1: 180 \\
1: 350 \\
1: 700\end{aligned}$ & $\begin{array}{r}4 \\
27 \\
19 \\
9\end{array}$ & $\begin{array}{r}100 \\
87 \\
87 \\
94\end{array}$ & $\begin{array}{c}0 \\
7 \pm 4.9 \\
5 \pm 5.0 \\
0\end{array}$ \\
\hline Arsenic trioxide-carrot.... & $\begin{array}{l}200 \\
100\end{array}$ & $\begin{array}{l}1: 70 \\
1: 140\end{array}$ & $\begin{array}{r}37 \\
4\end{array}$ & $\begin{array}{l}97 \\
88\end{array}$ & $\begin{array}{c}8 \pm 4.4 \\
0\end{array}$ \\
\hline Barium carbonate-carrot... & $\begin{array}{l}400 \\
200\end{array}$ & $\begin{array}{l}1: 35 \\
1: 70\end{array}$ & $\begin{array}{l}17 \\
14\end{array}$ & $\begin{array}{l}88 \\
96\end{array}$ & $\begin{array}{c}0 \\
14 \pm 9.2\end{array}$ \\
\hline Castrix-carrot.... & $\begin{array}{l}50 \\
20\end{array}$ & $\begin{array}{l}1: 280 \\
1: 700\end{array}$ & $\begin{array}{l}93 \\
13\end{array}$ & $\begin{array}{l}83 \\
96\end{array}$ & $\begin{array}{l}43 \pm 5.1 \\
38 \pm 13.4\end{array}$ \\
\hline
\end{tabular}


TABle 1 (Continued)

\begin{tabular}{|c|c|c|c|c|c|}
\hline \multirow{2}{*}{ Poison-bait } & \multicolumn{2}{|c|}{ Dosage } & \multirow{2}{*}{$\begin{array}{c}\text { Number } \\
\text { of burrows } \\
\text { baited }\end{array}$} & \multirow{2}{*}{$\begin{array}{c}\text { Acceptance, } \\
\text { per cent of } \\
\text { bait taken }\end{array}$} & \multirow{2}{*}{$\begin{array}{c}\text { Kill, per } \\
\text { cent of open } \\
\text { sites } \pm \text { S.E. }\end{array}$} \\
\hline & $\begin{array}{c}\text { Mg poison } \\
\text { per burrow }\end{array}$ & $\begin{array}{l}\text { Poison : Bait } \\
\text { ratio by wt. }\end{array}$ & & & \\
\hline Compound 1080-carrot.. & $\begin{array}{l}40 \\
20 \\
10 \\
10 \\
5 \\
5 \\
2.5 \\
2 \\
1\end{array}$ & $\begin{array}{l}1: 350 \\
1: 700 \\
1: 700 \\
1: 1,400 \\
1: 1,400 \\
1: 2,800 \\
1: 2,800 \\
1: 7,000 \\
1: 7,000\end{array}$ & $\begin{array}{l}35 \\
48 \\
16 \\
40 \\
11 \\
34 \\
34 \\
22 \\
24\end{array}$ & $\begin{array}{r}87 \\
95 \\
100 \\
90 \\
91 \\
85 \\
97 \\
95 \\
96\end{array}$ & $\begin{array}{l}74 \pm 7.4 \\
79 \pm 5.8 \\
94 \pm 5.9 \\
80 \pm 6.3 \\
82 \pm 12 \\
79 \pm 6.9 \\
88 \pm 5.5 \\
64 \pm 11 \\
42 \pm 10\end{array}$ \\
\hline Compound 1080 -sweet potato...... & $\begin{array}{l}20 \\
10 \\
5 \\
2.5\end{array}$ & $\begin{array}{l}1: 600 \\
1: 1,300 \\
1: 2,700 \\
1: 5,200\end{array}$ & $\begin{array}{l}22 \\
21 \\
19 \\
24\end{array}$ & $\begin{array}{l}93 \\
90 \\
84 \\
90\end{array}$ & $\begin{array}{c}82 \pm 8.1 \\
86 \pm 7.5 \\
84 \pm 8.4 \\
100\end{array}$ \\
\hline Compound 1080 -Irish potato... & $\begin{array}{r}20 \\
5\end{array}$ & $\begin{array}{l}1: 700 \\
1: 2,800\end{array}$ & $\begin{array}{l}22 \\
58\end{array}$ & $\begin{array}{l}77 \\
92\end{array}$ & $\begin{array}{l}73 \pm 10 \\
76 \pm 5.6\end{array}$ \\
\hline Compound 1080 -turnip $\ldots \ldots \ldots \ldots \ldots \ldots \ldots$ & 20 & $1: 700$ & 18 & 89 & $94 \pm 5.5$ \\
\hline Compound 1080-beet. . & 20 & $1: 700$ & 11 & 95 & $91 \pm 8.6$ \\
\hline Compound 1080-sugar beet.. & $\begin{array}{r}20 \\
5\end{array}$ & $\begin{array}{l}1: 700 \\
1: 2,800\end{array}$ & $\begin{array}{l}27 \\
20\end{array}$ & $\begin{array}{r}80 \\
100\end{array}$ & $\begin{array}{l}78 \pm 8.0 \\
70 \pm 10.2\end{array}$ \\
\hline Thallium sulfate-carrot... & $\begin{array}{l}250 \\
125\end{array}$ & $\begin{array}{l}1: 58 \\
1: 116\end{array}$ & $\begin{array}{r}8 \\
19\end{array}$ & $\begin{array}{l}94 \\
87\end{array}$ & $\begin{array}{l}25 \pm 15 \\
42 \pm 11\end{array}$ \\
\hline Zinc phosphide-carrot...... & $\begin{array}{l}80 \\
40\end{array}$ & $\begin{array}{l}1: 175 \\
1: 360\end{array}$ & $\begin{array}{l}23 \\
20\end{array}$ & $\begin{array}{l}96 \\
92\end{array}$ & $\begin{array}{l}26 \pm 9.1 \\
10 \pm 6.7\end{array}$ \\
\hline Zinc phosphide-sweet potato... & 80 & $1: 123$ & 12 & 96 & $25 \pm 12$ \\
\hline Zinc phosphide-Irish potato... & 80 & $1: 123$ & 7 & 78 & 0 \\
\hline Zinc phosphide-turnip.... & $\begin{array}{l}80 \\
40\end{array}$ & $\begin{array}{l}1: 123 \\
1: 123\end{array}$ & $\begin{array}{l}8 \\
4\end{array}$ & $\begin{array}{l}88 \\
90\end{array}$ & $\begin{array}{c}50 \pm 18 \\
0\end{array}$ \\
\hline Zinc phosphide-beet. & $\begin{array}{l}80 \\
40\end{array}$ & $\begin{array}{l}1: 123 \\
1: 123\end{array}$ & $\begin{array}{l}3 \\
1\end{array}$ & $\begin{array}{r}83 \\
100\end{array}$ & $\begin{array}{l}0 \\
0\end{array}$ \\
\hline 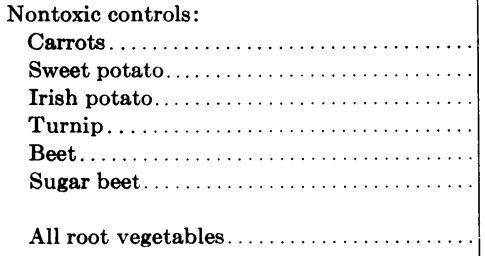 & $\begin{array}{l}. . \\
. \\
. \\
. \\
. \\
. \\
.\end{array}$ & $\begin{array}{l}\ldots \ldots \\
\ldots \ldots \\
\ldots \ldots \\
\ldots \ldots \\
\ldots \ldots \\
\ldots \ldots\end{array}$ & $\begin{array}{r}44 \\
11 \\
21 \\
6 \\
3 \\
4 \\
- \\
89\end{array}$ & $\begin{array}{r}96 \\
90 \\
100 \\
90 \\
100 \\
100\end{array}$ & $\begin{array}{c}2 \pm 2.1 \\
0 \\
0 \\
17 \pm 15 \\
0 \\
0 \\
2 \pm 1.5\end{array}$ \\
\hline
\end{tabular}


from a low level of 0 to 3 per cent when dosages up to $25 \mathrm{mg}$ per piece of bait were used, to 12 per cent when a massive dosage of $50 \mathrm{mg}$ per piece was applied. Castrix (sample A)-carrot baits at a dosage of $25 \mathrm{mg}$ per piece were completely refused in 8 out of 58 burrows baited (14 per cent), but Castrix (sample B) on carrots showed only 3 per cent refusal at the same

TABLE 2

FIELD TESTS WITH STRYCHNINE ALKALOID AND COMPOUND 1080 ON FRUIT BAITS

\begin{tabular}{|c|c|c|c|c|c|}
\hline \multirow{2}{*}{ Poison-bait } & \multicolumn{2}{|c|}{ Dosage } & \multirow{2}{*}{$\begin{array}{c}\text { Number } \\
\text { of burrows } \\
\text { baited }\end{array}$} & \multirow{2}{*}{$\begin{array}{l}\text { Acceptance, } \\
\text { per cent of } \\
\text { bait taken }\end{array}$} & \multirow{2}{*}{$\begin{array}{c}\text { Kill, per } \\
\text { cent of open } \\
\text { sites } \pm \text { S.E. }\end{array}$} \\
\hline & $\begin{array}{l}\text { Mg poison } \\
\text { per burrow }\end{array}$ & $\begin{array}{l}\text { Poison : Bait } \\
\text { ratio by wt. }\end{array}$ & & & \\
\hline \multicolumn{6}{|l|}{ Strychnine alkaloid-prunes } \\
\hline a. Dry $\ldots \ldots \ldots \ldots \ldots \ldots$ & 50 & $1: 280$ & 37 & 99 & $57 \pm 8.1$ \\
\hline $\begin{array}{l}\text { b. Soaked } \ldots \ldots \ldots \ldots \ldots \ldots \\
\text { Strychnine alkaloid-raisins }\end{array}$ & 50 & $1: 280$ & 56 & 96 & $73 \pm 5.9$ \\
\hline \multicolumn{6}{|l|}{ Strychnine alkaloid-raisins } \\
\hline a. Dry $\ldots \ldots \ldots \ldots \ldots \ldots$ & 50 & $1: 280$ & 45 & 92 & $36 \pm 7.1$ \\
\hline b. Soaked $\ldots \ldots \ldots \ldots \ldots \ldots \ldots \ldots$ & 50 & $1: 280$ & 22 & 83 & $60 \pm 10$ \\
\hline \multicolumn{6}{|l|}{ Strychnine alkaloid-apples } \\
\hline a. Dried $\ldots \ldots \ldots \ldots \ldots \ldots \ldots \ldots$ & 50 & $1: 280$ & 11 & 77 & $73 \pm 13$ \\
\hline b. Fresh ............. & 50 & $1: 280$ & 25 & 88 & $56 \pm 9.9$ \\
\hline Strychnine alkaloid-peaches (dried).. & 50 & $1: 280$ & 14 & 75 & $71 \pm 12$ \\
\hline Strychnine alkaloid-pears (dried). . & 50 & $1: 280$ & 13 & 92 & $77 \pm 12$ \\
\hline Strychnine alkaloid-apricots (dried) ... & 50 & $1: 280$ & 26 & 90 & $69 \pm 9.0$ \\
\hline Strychnine alkaloid-quince (fresh) . . . . . . . & 50 & $1: 280$ & 17 & 100 & $59 \pm 12$ \\
\hline \multicolumn{6}{|l|}{ Compound 1080-prunes } \\
\hline a. Dry $\ldots \ldots \ldots$ & 20 & $1: 700$ & 18 & 95 & $78 \pm 9.7$ \\
\hline b. Soaked ............. & 20 & $1: 700$ & 17 & 97 & $88 \pm 7.9$ \\
\hline \multicolumn{6}{|l|}{ Compound 1080-raisins } \\
\hline a. Dry................ & 20 & $1: 700$ & 15 & 90 & $73 \pm 11.4$ \\
\hline b. Soaked .................... & 20 & $1: 700$ & 30 & 97 & $73 \pm 8.1$ \\
\hline Compound 1080-apples (fresh). . & 5 & $1: 2,800$ & 20 & 90 & $65 \pm 11$ \\
\hline \multicolumn{6}{|l|}{ Nontoxic controls: } \\
\hline Prunes (dry) & . & $\ldots \ldots$ & 11 & 95 & $9 \pm 8.6$ \\
\hline Prunes (soaked).. & . & $\ldots \ldots$ & 3 & 100 & 0 \\
\hline Raisins (dry).... & . & $\ldots \ldots$ & 5 & 98 & 0 \\
\hline Apples (fresh).. & . & $\ldots \ldots$ & 4 & 100 & 0 \\
\hline Apricots (dried)... & . & $\ldots \ldots$ & 4 & 88 & 0 \\
\hline Quince (fresh) $\ldots \ldots \ldots \ldots \ldots \ldots \ldots \ldots \ldots \ldots$ & . & $\ldots \ldots$ & 3 & 100 & 0 \\
\hline All fruits.. & & & 30 & 96 & $3 \pm 3.1$ \\
\hline
\end{tabular}

dosage level. These refusals are obviously reflected in decreased field-kill percentages. In about 11 per cent of all burrows treated with poisoned bait only half the bait was taken, that is, only one of the two pieces offered. This partial acceptance occurred also in 5 per cent of burrows when nontoxic baits were used. Combining partial and complete acceptance percentages raises the average of burrows in which some poison bait was taken to 97 per cent, with a range of 86 to 100 per cent. In certain instances, failure of the gopher to take all the bait may be due to the fact that it was overcome before it could dispose of all that was offered, especially if bait sites were far apart or a fast-acting poison was used. Occasional finds of dead gophers near partly consumed bait confirms this inference. 
Of more practical interest are field-kill percentages which, by definition, involve acceptance as well as toxicity. On the basis of highest field-kills obtained with carrot bait (regardless of dosage), the several poisons tested may be grouped into three categories. Heading the list are Compound 1080 and strychnine alkaloid, with best field-kills on the order of 80 per cent,

TABLE 3

FIELD TESTS WITH FIVE POISONS (STRYCHNINE ALKALOID, COMPOUND 1080, CASTRIX, THALLIUM SULFATE, AND ZINC PHOSPHIDE) ON GRAIN BAITS

\begin{tabular}{|c|c|c|c|c|c|}
\hline \multirow{2}{*}{ Poison-bait } & \multicolumn{2}{|c|}{ Dosage } & \multirow{2}{*}{$\begin{array}{l}\text { Number } \\
\text { of burrows } \\
\text { baited }\end{array}$} & \multirow{2}{*}{$\begin{array}{l}\text { Acceptance, } \\
\text { per cent of } \\
\text { bait taken }\end{array}$} & \multirow{2}{*}{$\begin{array}{c}\text { Kill, per } \\
\text { cent of open } \\
\text { sites } \pm \text { S.E. }\end{array}$} \\
\hline & $\begin{array}{l}\text { Mg poison } \\
\text { per burrow }\end{array}$ & $\begin{array}{l}\text { Poison : Bait } \\
\text { ratio by wt. }\end{array}$ & & & \\
\hline 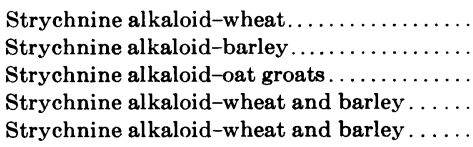 & $\begin{array}{l}50 \\
50 \\
50 \\
68 \\
34\end{array}$ & $\begin{array}{l}1: 280 \\
1: 280 \\
1: 280 \\
1: 256 \\
1: 256\end{array}$ & $\begin{array}{l}40 \\
35 \\
53 \\
11 \\
27\end{array}$ & $\begin{array}{r}99 \\
100 \\
85 \\
75 \\
87\end{array}$ & $\begin{array}{l}18 \pm 6.0 \\
26 \pm 7.4 \\
40 \pm 6.7 \\
27 \pm 13.4 \\
41 \pm 10.0\end{array}$ \\
\hline $\begin{array}{l}\text { Castrix-oat groats } \ldots \ldots \ldots \ldots \ldots \ldots \ldots \ldots \ldots \ldots \\
\text { Compound } 1080 \text {-wheat........ } \\
\text { Compound } 1080 \text {-barley } \ldots \ldots \ldots \ldots \ldots \ldots \ldots \ldots \ldots \ldots \ldots \ldots \\
\text { Compound } 1080 \text {-oat groats } \ldots \ldots \ldots \ldots \ldots \ldots \ldots\end{array}$ & $\begin{array}{l}50 \\
20 \\
20 \\
20 \\
10 \\
5 \\
2.5 \\
1.25 \\
0.62\end{array}$ & $\begin{array}{l}1: 280 \\
1: 700 \\
1: 700 \\
1: 700 \\
1: 1,400 \\
1: 2,800 \\
1: 5,600 \\
1: 11.200 \\
1: 22,400\end{array}$ & $\begin{array}{l}19 \\
44 \\
33 \\
85 \\
36 \\
39 \\
23 \\
27 \\
22\end{array}$ & $\begin{array}{r}82 \\
99 \\
97 \\
88 \\
93 \\
96 \\
100 \\
94 \\
100\end{array}$ & $\begin{array}{l}68 \pm 11 \\
86 \pm 5.2 \\
67 \pm 8.1 \\
86 \pm 3.7 \\
92 \pm 4.2 \\
82 \pm 6.1 \\
61 \pm 10 \\
70 \pm 8.8 \\
55 \pm 11\end{array}$ \\
\hline Thallium sulfate-wheat and barley . ........ & 90 & $1: 156$ & 7 & .. & $29 \pm 17$ \\
\hline Zinc phosphide-wheat and barley......... & $\begin{array}{r}112 \\
56\end{array}$ & $\begin{array}{l}1: 160 \\
1: 250\end{array}$ & $\begin{array}{l}3 \\
6\end{array}$ & $\begin{array}{r}75 \\
100\end{array}$ & $\begin{array}{l}0 \\
0\end{array}$ \\
\hline 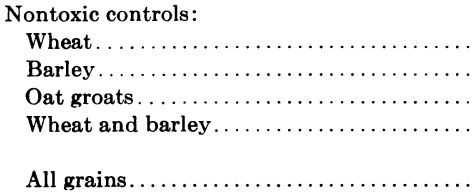 & $\begin{array}{l}\cdots \\
\cdots \\
\cdots \\
\cdots\end{array}$ & $\begin{array}{l}\cdots \cdots \\
\cdots \cdots \\
\cdots \cdots\end{array}$ & $\begin{array}{r}3 \\
5 \\
16 \\
5 \\
29\end{array}$ & $\begin{array}{l}100 \\
100 \\
100 \\
100 \\
100\end{array}$ & $\begin{array}{c}0 \\
0 \\
6 \pm 5.9 \\
0 \\
3 \pm 3.1\end{array}$ \\
\hline
\end{tabular}

closely followed by strychnine sulfate with highest field-kill of 77 per cent. Castrix and thallium sulfate comprise the second group, with best fieldkills on carrots ranging between 40 and 50 per cent, significantly less effective than the preceding group. These two poisons showed enough promise, however, to warrant further test with other kinds of bait, as reported later.

All other compounds tested may be classed as poor poisons for gophers since the best field-kills obtained with them on carrots were less than 30 per cent. In descending order of effectiveness, the inferior group includes zinc phosphide, ANTU, barium carbonate, and arsenic trioxide.

For practical purposes, it is sometimes important to demonstrate which poisons are not effective as well as those that are. A case in point is zine 
phosphide. Because this is commonly and often quite effectively used for eradication of ground squirrels, many inquiries have been received as to the possibility of using this poison for gophers too. Without prior evaluation tests, it would be impossible to advise against the use of zine phosphide for gopher control.

Several reasons may be advanced to account for the poor or mediocre showing of some of the baits tested. The fact that some kills were obtained with poisons low on the list of effectiveness and that all of them would doubtless prove lethal if forcibly administered in the laboratory indicates that palatability and similar factors play an important role in the success of a poison bait. Zine phosphide baits are suspect on point of acceptability since this poison, when wet, emits a strong odor of phosphine gas, which may repel the gopher. Thus it was observed that zine phosphide baits were frequently pushed out of the burrow by the gopher in plugging open-bait sites. Taste as well as odor may be involved, but it is erroneous to assume that what may be distasteful to man is also distasteful to another species. Also, individuals within a species may differ in taste perception. Among human beings, for instance, it has been shown that there are "taste-blind" persons, who cannot detect the bitter taste of phenylthiocarbamide (a compound closely related to ANTU) or even of strychnine.

Failure of ANTU might be attributed to the fact that toxicity of this compound appears to be rather specifically limited to the Norway rat. Other varieties of rats are not killed by it, nor apparently are gophers to any great extent.

The foregoing ratings are based on kills obtained in tests of relatively short duration, allowing, at most, an interval of only three or four days between setting baits and opening bait sites. These tests, therefore, give little or no information on long-term, cumulative, or sublethal effects of poisons. It was observed, however, that when highly toxic baits were used, earth plugs (when present) in bait sites were frequently small, and sometimes barely large enough to close the tunnel openings; but when nontoxic or ineffective baits were used, plugs were large and usually filled the entire bait-site excavation to ground level. These observations lead one to suspect that the small plugs were probably made by sick gophers that might have succumbed in time, or that, in a weakened condition, might easily have fallen prey to natural enemies. It is possible, of course, that small plugs may have been made in some instances by juveniles that had not yet dispersed from the parental burrow.

In this analysis no attempt was made to classify the animals except as dead or alive-using closed sites, regardless of the amount of plugging, as the criterion of survival. For the present it is felt that long-term, cumulative, or sublethal effects may be disregarded and that any poison that does not kill within a few days after acceptance should be rejected in favor of one that does. More or less immediate kills with one or but few applications of bait would seem to be the primary objective in control of gophers by poisoning. Compound 1080 and the two strychnines accomplish this purpose, giving high percentages of kill with each treatment.

Unfortunately, the high toxicity of Compound 1080 is not limited to 
rodents. It is known to be lethal, sometimes in extremely small amounts, to many other mammals and birds (Ward and Spencer, 1947) including domestic livestock, poultry, pets, wildlife, game birds such as ducks, doves, and quail (Sayama and Brunetti, 1952), monkeys, and man. Several accidental human deaths have been reported. Its high potency, together with the fact that there are no specific symptoms of 1080-poisoning and no antidote for it (as yet), makes it entirely too dangerous for distribution to the general public. The hazards of accidental and secondary poisoning with 1080 are further increased by its ready solubility and lack of distinctive color or odor (it comes in white powdery form resembling baking soda or similar innocuous substances, and in aqueous solution it is clear). Hence the possession and use of Compound 1080 are limited by law to certain responsible and qualified persons (for regulations in California, see Section 1066.6 of the Agricultural Code). Noteworthy progress on the development of an antidote has recently been reported by Tourtelotte and Coon (1951), who show that sodium acetate and ethanol, if administered immediately, will antagonize 1080 poisoning. Although discovery of an antidote would eliminate one serious obstacle, it is doubtful that present restrictions on the use of Compound 1080 can be lifted to any great extent because the grave danger of accidental and secondary poisoning still remains. The strychnines, however, are available to the general public as effective gopher poisons.

\section{Baits}

In this section baits rather than poisons will be considered the primary variable, and comparisons will be made of different bait materials with poison and dosage constant. The bait materials tested may be divided into four classes: root vegetables (table 1), grains (table 2), fruits, mainly dried (table 3 ), and proprietary poisons (table 4 ). Within each class, several kinds of baits were tried. Root vegetables tested, for example, include carrots, sweet and Irish potatoes, turnips, beets, and sugar beets.

In general, with few exceptions, there seem to be no consistent or significant differences in acceptance or field kill between various kinds of bait within a given class when these are treated with equivalent dosages of the same poison (table 2). Among the root vegetables, for instance, one seems as effective, within the experimental error, as any other. With strychnine-coated vegetables (except turnips) at a dosage of $50 \mathrm{mg}$ per burrow acceptance ranged between 85 and 96 per cent and field-kills between 64 and 80 per cent. The maximal 16 per cent difference in field-kill (between Irish potatoes and carrots) is not statistically significant, being obviously less than twice its standard error. The low acceptance (68 per cent) and field-kill (only 32 per cent) with strychnine-coated turnips at a $50 \mathrm{mg}$ per burrow dosage is inconsistent since at a much lower dosage (20 mg per burrow) turnips were well accepted and gave a 71 per cent kill. Also good acceptance and a high kill were obtained with turnips poisoned with Compound 1080 (see table 1).

Best field-kills with strychnine-coated vegetables, regardless of dosage, range from 70 per cent (sugar beets) to 91 per cent (beets). The difference of $21 \pm 11.5$ per cent between the extremes is not statistically significant. 
Hence it appears that practically all root vegetables with equivalent dosages of strychnine are equally effective and give good kills.

On grains, strychnine gave somewhat variable results, with kills ranging between 18 and 41 per cent. Strychnine-coated wheat gave the lowest percentage of kill (only 18 per cent), significantly less than whole-oat groats or mixed grain (wheat and barley). These data clearly show that with strychnine grain baits are much inferior to vegetable baits for pocket gophers.

Fruit baits were in general not quite so effective as vegetables with strychnine, but definitely superior to grain baits. Best kills with strychnine-coated fruit baits (except dry raisins) ranged from 56 to 77 per cent, fresh fruits (apples and quince) being at the lower end of the range.

With Compound 1080, all bait materials tested were well accepted, and almost all gave high kills. Disregarding dosages, best kills with 1080-poisoned baits ranged as follows: on root vegetables, from 78 per cent (sugar beet) to 100 per cent (sweet potatoes); on grain, from 67 per cent (barley) to 92 per cent (oat groats); and on fruit, from 65 per cent (fresh apples) to 88 per cent (soaked prunes). With few exceptions differences in effectiveness of 1080 baits, both within and between classes, were not significant.

Zine phosphide was ineffective on all bait materials with which it was tried. Best kills with this poison (when more than 12 burrows were baited) were 26 per cent with carrots and 25 per cent with sweet potatoes. The 50 per cent kill obtained on turnip bait carrying a dosage of $40 \mathrm{mg}$ of zinc phosphide per piece ( $80 \mathrm{mg}$ per burrow) may be disregarded since only eight burrows were baited at this dosage, a number too small for a reliable test, as shown by the large standard error of 18 per cent. No kills were obtained with zine phosphide-coated grain in nine burrows tested. This poison was not tried on fruit baits.

Since Castrix and thallium sulfate showed some promise on vegetable baits, a few tests were made with these poisons on grain. Castrix on grain gave a kill of 68 per cent, which is $25 \pm 12$ per cent greater than that obtained with carrots-a significant increase, but still not enough to recommend its use. On grain, thallium sulfate gave about the same kill as on carrots-29 per cent on grain as compared to 25 per cent on carrots.

Several reasons may be suggested for the demonstrated differences in effectiveness between classes of bait treated with equivalent dosages of the same poison, for example, between grain and root vegetables poisoned with strychnine. Since acceptance percentages are practically the same for all kinds of bait, the manner of their removal from bait sites by the gopher and their later disposition are crucial questions. It was previously supposed that size of bait is an important factor, since the fur-lined cheek pouches of gophers are impermeable to poison. Consequently, small baits like grain and raisins that a gopher could pouch directly would be less effective than larger baits because, in gnawing large baits to pouchable size, the animal presumably would ingest a lethal dosage of poison. The bait-size theory was refuted (1) by field tests showing that standard-sized carrot and prune baits when cut into small pieces are just as effective with strychnine as larger baits, and (2) by observations that caged and field gophers do not necessarily cut large pieces of bait or even whole carrots for pouching but may drag or 
carry them entire for long distances through the burrow (Miller and Howard, 1951). Thus a more likely explanation for greater effectiveness of root-vegetable baits is that they are probably eaten more or less immediately after being discovered, whereas less perishable baits like grain and raisins may be carried with impunity in the gopher's cheek pouches and cached. Cached baits may be forgotten, spoil, or lose their potency.

Although this explanation might account for the great difference in effectiveness between strychnine-coated grain and vegetable baits, it does not explain why grain and vegetable baits poisoned with Compound 1080 are

TABLE 4

FIELD TESTS WITH PROPRIETARY GOPHER BAITS CONTAINING STRYCHNINE AS THE ACTIVE INGREDIENT*

\begin{tabular}{|c|c|c|c|c|c|c|}
\hline \multirow[b]{2}{*}{ Brand $\dagger$ and inert ingredients } & \multirow{2}{*}{$\begin{array}{c}\text { Percentage } \\
\text { of } \\
\text { strychnine } \\
\text { stated } \\
\text { on label }\end{array}$} & \multicolumn{2}{|c|}{ Dosage } & \multirow{2}{*}{$\begin{array}{c}\text { Number } \\
\text { of } \\
\text { burrows } \\
\text { baited }\end{array}$} & \multirow{2}{*}{$\begin{array}{l}\text { Accept- } \\
\text { ance, } \\
\text { per cent } \\
\text { of bait } \\
\text { taken }\end{array}$} & \multirow{2}{*}{$\begin{array}{c}\text { Kill, } \\
\text { per cent } \\
\text { of } \\
\text { open sites } \\
\pm \text { S.E. }\end{array}$} \\
\hline & & $\begin{array}{l}\text { Bait per } \\
\text { burrow }\end{array}$ & $\begin{array}{c}\text { Mg poison } \\
\text { per burrow } t\end{array}$ & & & \\
\hline A. Finely ground dried fruit, grain.. & 0.43 & $\begin{array}{l}2 \text { heaping } \\
\text { teaspoons }\end{array}$ & c. 0.50 & 19 & 78 & $10 \pm 7$ \\
\hline B. Scented pellets. . & 0.50 & $\begin{array}{l}10 \text { pellets } \\
5 \text { pellets } \\
3 \text { pellets } \\
2 \text { pellets } \\
1 \text { pellet }\end{array}$ & $\begin{array}{r}20 \\
10 \\
6 \\
4 \\
2\end{array}$ & $\begin{array}{r}5 \\
8 \\
24 \\
17 \\
14 \\
\end{array}$ & $\begin{array}{r}100 \\
100 \\
88 \\
91 \\
100\end{array}$ & $\begin{array}{l}80 \pm 18 \\
88 \pm 12 \\
58 \pm 10 \\
71 \pm 11 \\
64 \pm 13\end{array}$ \\
\hline C. Grain, dried fruit, and aromatics. & 0.30 & $\begin{array}{r}2 \text { tablespoons } \\
1 \text { tablespoon }\end{array}$ & $\begin{array}{l}\text { c. } 0.50 \\
\text { c. } 0.25\end{array}$ & $\begin{array}{l}29 \\
28\end{array}$ & $\begin{array}{l}66 \\
75\end{array}$ & $\begin{array}{l}62 \pm 9 \\
36 \pm 9\end{array}$ \\
\hline D. Grain and aromatics. & 0.29 & $\begin{array}{c}2 \text { tablespoons } \\
1 \text { tablespoon }\end{array}$ & $\begin{array}{l}\text { c. } 0.50 \\
\text { c. } 0.25\end{array}$ & $\begin{array}{l}28 \\
28\end{array}$ & $\begin{array}{l}87 \\
84\end{array}$ & $\begin{array}{l}50 \pm 9 \\
54 \pm 9\end{array}$ \\
\hline
\end{tabular}

* The majority of these tests were conducted by Mrs. Shirley E. Downie under superivsion of the author. $\dagger$ Trade names withheld.

$\ddagger$ Weight of bait offered $x$ stated percentage of poison.

equally potent nor why grain baits gave high kills when poisoned with 1080 but poor results with strychnine. The reason for these discrepancies must stem from the fact that Compound 1080 is much more toxic and more highly soluble than strychnine. As will be seen later, the median lethal field dosage for Compound 1080 is less than $1 / 2$ milligram per burrow, while for strychnine it is about $10 \mathrm{mg}$ per burrow. Also, Compound 1080 is readily soluble in water, whereas strychnine alkaloid is practically insoluble. Thus a minute amount of Compound 1080 accidentally getting on the tongue or moist membrane lining the mouth of the gopher during pouching or other manipulation of bait would quickly be absorbed and be lethal, while the chances of such accidental poisoning with strychnine would appear slight.

Four proprietary baits containing strychnine were tested for comparison with experimental strychnine baits (table 4). All but one of these (Brand A) gave fair field-kills at recommended dosages, and about what would be predicted from their ingredients. Brand $\mathrm{D}$, for example, a strychnine-coated grain bait (plus aromatics) gave kills essentially comparable to those obtained with experimental grain baits ; and Brand $\mathrm{C}$, composed of a mixture of grains 
and dried fruits (plus aromatics), gave kills intermediate between experimental grain and dried fruit. Brand A contained much the same basic ingredients as Brand $\mathrm{C}$, but the mixture was much more finely ground; this fact may be associated with its failure (only 10 per cent field-kill).

Acceptance of Brand $\mathrm{C}$ bait was relatively poor-in fact, the lowest of any experimental or proprietary bait tested. In addition to the ingredients listed, this bait contains many other substances including antigerminants, insecticides, mold deterrents, and dyes. The colors doubtless are solely for appeal (and warning) to customers because rodents are color-blind and gopher baits are placed underground in dark tunnels. The taste or odor of some of these added ingredients may have a repellent effect, thus lowering acceptance and hence efficiency of the bait.

Only one of the proprietary strychnine baits (Brand B) gave as high field-kills as those obtained with the best experimental baits with the same poison-namely, strychnine-coated root vegetables. To obtain such kills, a minimum of about five pellets per burrow was required. At a cent a pellet, cost of materials would be at least 5 cents per gopher, as compared to about two thirds of a cent for strychnine alkaloid-carrot bait ( see table 14). For eradicating an occasional gopher, the convenience of having at hand a readymade proprietary bait might compensate for the extra cost; but for largescale gopher control, fresh baits can be easily prepared at a great saving in cost.

To summarize this and the preceding section, the following conclusions may be drawn:

1. One kind of root vegetable, fruit, or grain is just as effective as any other with a given poison, but between these three classes of bait there may or may not be differences in performance, depending upon the poison used, as shown in the following summary.

\section{Rating of Poison Baits for Pocket Gophers}

\begin{tabular}{|c|c|c|}
\hline Kill & Bait & Poison \\
\hline \multirow[t]{3}{*}{$\begin{array}{l}\text { Good } \\
\quad(\text { Greater than } 70 \text { per cent) }\end{array}$} & $\begin{array}{l}\text { Root vegetables } \\
\quad \text { (mainly carrots) }\end{array}$ & $\begin{array}{l}\text { Compound } 1080, \text { strychnine } \\
\text { alkaloid, strychnine sulfate }\end{array}$ \\
\hline & $\begin{array}{l}\text { Grain } \\
\text { (wheat, barley, } \\
\text { oat groats) }\end{array}$ & Compound 1080 \\
\hline & $\begin{array}{l}\text { Fruits } \\
\quad \text { (mainly dried) }\end{array}$ & $\begin{array}{l}\text { Compound } 1080 \text {, occasionally } \\
\text { strychnine alkaloid }\end{array}$ \\
\hline \multirow{3}{*}{$\begin{array}{l}\text { Fair } \\
\quad(40-70 \text { per cent })\end{array}$} & Root vegetables & Castrix, thallium sulfate \\
\hline & $\begin{array}{l}\text { Grain } \\
\quad \text { (oat groats) }\end{array}$ & Castrix \\
\hline & Fruits & Strychnine alkaloid \\
\hline \multirow[t]{2}{*}{$\begin{array}{l}\text { Poor } \\
\quad \text { (Less than } 40 \text { per cent) }\end{array}$} & Root vegetables & $\begin{array}{l}\text { ANTU, arsenic trioxide, bar- } \\
\text { ium carbonate, zinc phos- } \\
\text { phide }\end{array}$ \\
\hline & Grain & $\begin{array}{l}\text { Strychnine alkaloid, zine } \\
\text { phosphide, thallium sulfate }\end{array}$ \\
\hline
\end{tabular}




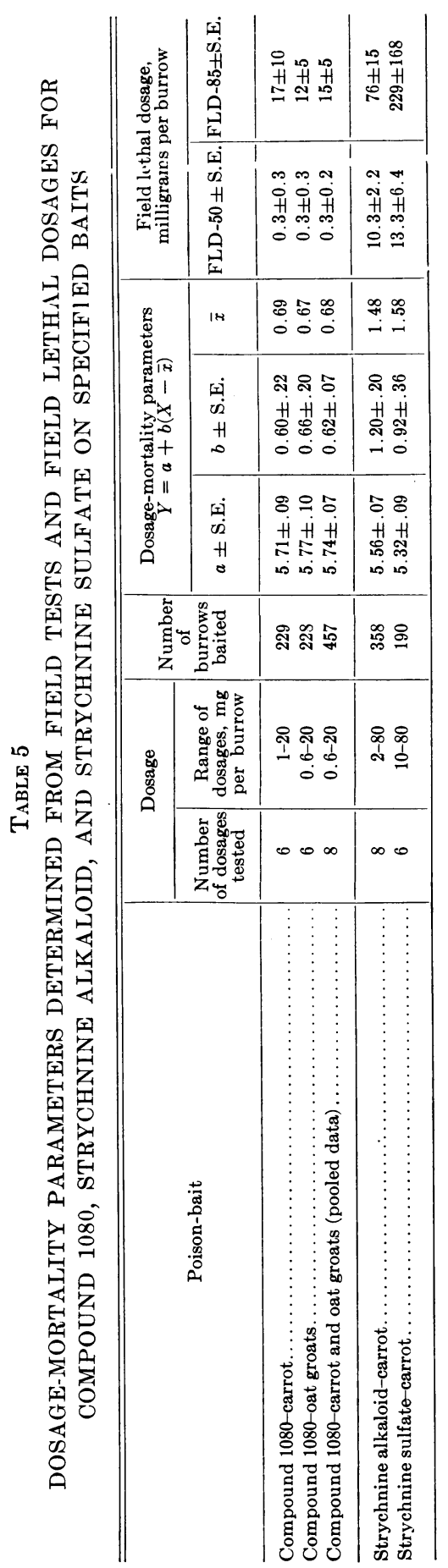


2. Performance of proprietary poisons may be fairly predicted, if ingredients are known, on the basis of the foregoing table. Only one of four brands tested gave kills comparable to the best experimental baits, but at a relatively high cost for materials.

\section{Practical Field Dosages}

Determination of dosages of poisons for field use was a major and practical objective of this investigation. Accordingly, both field and laboratory tests were made, using graded dosages of three poisons (Compound 1080, strychnine alkaloid, and strychnine sulfate) that gave practical field-kills on standard baits. From the data obtained dosage-mortality curves were computed by probit analysis (Finney, 1947), from which practical lethal dosages could be estimated.

Probit analysis. In essence, probit analysis converts the normal sigmoid dosage-mortality curve into a straight line-a transformation that has obvious advantages. The first step in the procedure is to translate kill percentages into probit units and to plot these against the logarithms of the corresponding dosages. Tables (Finney, 1947; or Bliss, 1935) or probit-ruled graph paper are available for converting kill percentages to probits. When so plotted, dosage-mortality data points tend to fall along a straight line that can be drawn by eye or computed. The equation for the probit regression is:

$$
Y=a+b(X-\bar{x})
$$

where $Y=$ mortality in probit units,

$X=$ logarithm of any given dosage,

$\bar{x}=$ logarithm of the weighted-mean dosage,

$a=$ a parameter representing probit mortality at the mean dosage, that is, the value of $Y$ when $(X-\bar{x})=0$,

$b=$ a parameter indicating the slope of the probit-regression line.

Methods for estimating standard errors and fiducial probabilities are described by Finney (1947), Litchfield and Fertig (1941), and Litchfield and Wilcoxon (1949). Finney's longer but more accurate methods are here employed.

Field tests. Field-test methods and results (tables 1 to 4 ) have already been described. Probit analyses of the pertinent data from these tests are presented in table 5 and in figure 3.

In setting up the data for analysis, kill percentages for each dosage of a given poison bait were pooled; that is, poison:bait ratios were disregarded since the amounts of bait, within practical limits, seemed immaterial as long as the dosage of poison was constant. The validity of this assumption is shown by comparing kill percentages obtained in the few tests where the same total amount of poison was administered on varying amounts of bait (table 1). For example, in two series using carrot baits poisoned with Compound 1080 at a dosage of $5 \mathrm{mg}$ per burrow, practically identical kills of $82 \pm 12$ per cent and $79 \pm 7$ per cent were obtained (table 1 ). The only difference between the two series is that in the first the entire 5-mg dosage was carried into each burrow on one 7-gram piece of carrot (poison:bait ratio of $1: 1,400$ ) ; while in the second each burrow received two 7 -gram baits 
each carrying $2.5 \mathrm{mg}$ of poison (poison:bait ratio of 1:2,800). The only instance where kill percentages could not be lumped was in tests with strychnine alkaloid-carrot bait at $100 \mathrm{mg}$ per burrow dosage, because here a large, significant difference in field-kill was obtained in two series differing only in poison:bait ratios (see table 1 ).

To distinguish lethal dosages determined by field tests from conventional LD estimates established by laboratory procedures (see later), the term

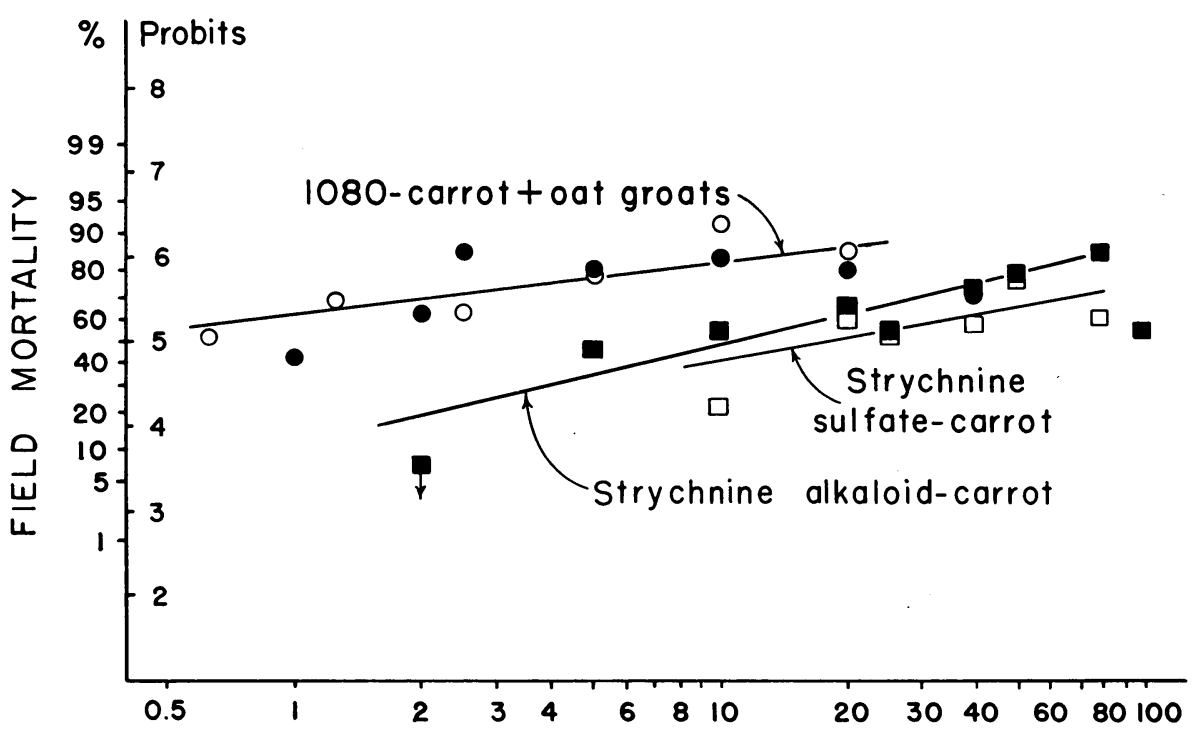

DOSAGE Milligrams of poison per burrow

Fig. 3. Dosage-mortality regressions computed from field tests using graded dosages of Compound 1080 on oat groats (open circles) and carrots (filled circles), of strychnine alkaloid on carrot (filled squares), and of strychnine sulfate on carrot (open squares). Mortality given both in probit units and in field-kill percentages; dosages plotted logarithmically. Regression line for Compound 1080 computed from pooled data for carrots and oat-groat baits. Kills with $40 \mathrm{mg} /$ burrow of Compound 1080 on carrot and with $100 \mathrm{mg} / \mathrm{bur}$ row of strychnine alkaloid on carrot were omitted in calculating regressions.

field lethal dosage, abbreviated FLD, is here introduced. The level of kill will be designated in the usual way by appending the appropriate percentage of kill value to the abbreviation (thus FLD-50 refers to the dosage needed to kill 50 per cent of gophers baited in the field). From data already presented it is obvious that the bait material used with each poison must always be specified when expressing FLDs.

Probit plotting of field-kill percentages against the logarithm of the dosage shows that the data points fall along a straight line, mortality increasing regularly with dosage except at the highest dosages tested (fig. 3). Fieldkills with $40 \mathrm{mg}$ per burrow of Compound 1080 and with $100 \mathrm{mg}$ per burrow of strychnine alkaloid fell off so markedly that those data points had to be excluded in computing the dosage-mortality regressions for these two poisons 
in order to get "good-fitting" lines (applying the chi-square test). As suggested earlier, the reduction in field-kill percentages at massive dosages is most probably due to decreased acceptance of overdosed bait.

The relative potencies of the three poisons tested may be demonstrated by comparing dosages needed to give specified kills as estimated from dosagemortality curves. Since regression lines for these poisons are not parallel, it is obvious that their relative potencies change with dosage, and that comparisons should be made at more than one level of kill. For present purposes, the 50 and 85 per cent kills were selected. The 50 per cent value has long been a conventional standard, since it is usually near the average dosage tested and at this point statistical error in probit analysis is theoretically at a minimum (in contrast to statistical error of percentages that are inherently maximal at 50 per cent). The 85 per cent kill was selected because it represents about the highest average field-kills actually obtained-a value, therefore, of practical importance.

The high absolute and relative potency of Compound 1080 is shown by the fact that its FLD-50 (with carrots, oat groats, or both) is only $0.3 \mathrm{mg}$ per burrow as compared with FLD-50's of about 10 and $13 \mathrm{mg}$ per burrow for strychnine alkaloid-carrot and strychnine sulfate-carrot baits, respectively. In other words, at the 50 per cent level of field-kill, Compound 1080 is about 33 times as potent as strychnine alkaloid and about 44 times as effective as strychnine sulfate. At the more practical 85 per cent level of kill, Compound 1080 on carrots is $41 / 2$ times as potent as strychnine alkaloid and over 13 times as effective as strychnine sulfate on the same bait. The progressive decrease in ratios of equally effective dosages at higher levels of kills with these poisons is graphically represented, of course, by the convergence of the probit-regression lines of Compound 1080 with those for the two strychnines, the line for Compound 1080 having a relatively gradual slope ( $b$ only 0.6 as compared to 1.2 for strychnine alkaloid).

The observed differences in field performance between the two forms of strychnine may prove to be of considerable practical importance. Comparing equally effective dosages, it is noted that at FLD-50 strychnine alkaloid is about 1.3 times as potent as the sulfate, and that with increased dosage this ratio increases (as the dosage-mortality curves for the two strychnines diverge) until, at FLD-85, strychnine alkaloid is found to be about three times as effective as the sulfate. Statistically, these differences are not significant, but it is suggestive that all six data points for strychnine sulfate fall below the computed probit-regression line for the alkaloid, and each one lies below the corresponding points for the same dosages of alkaloid. Moreover, in one or possibly two instances, differences between corresponding points are statistically significant, namely, for kills with the two poisons at 10 and at $80 \mathrm{mg}$ per burrow (see table 1 and fig. 3 ).

Further tests would probably confirm the suspicion that the alkaloid form of strychnine is more potent than the sulfate, at least in poisoning pocket gophers. This is at variance with the often repeated statement that the two forms of strychnine are equally effective. Further evidence that they are not, so far as gophers are concerned, was found in laboratory tests next to be considered. 
Laboratory tests. Methods for the laboratory bioassays of Compound 1080, strychnine alkaloid, and strychnine sulfate were as follows. Captive gophers were fed small carrot cubes containing precisely measured amounts of poison. To prepare these baits, fresh carrots were first cut into $3 / 8$-inch cubes from each of which a cylindrical plug, $3 / 16$ inch in length and diameter, was extracted with a cork borer. The cubes were dried for two days at room tem-

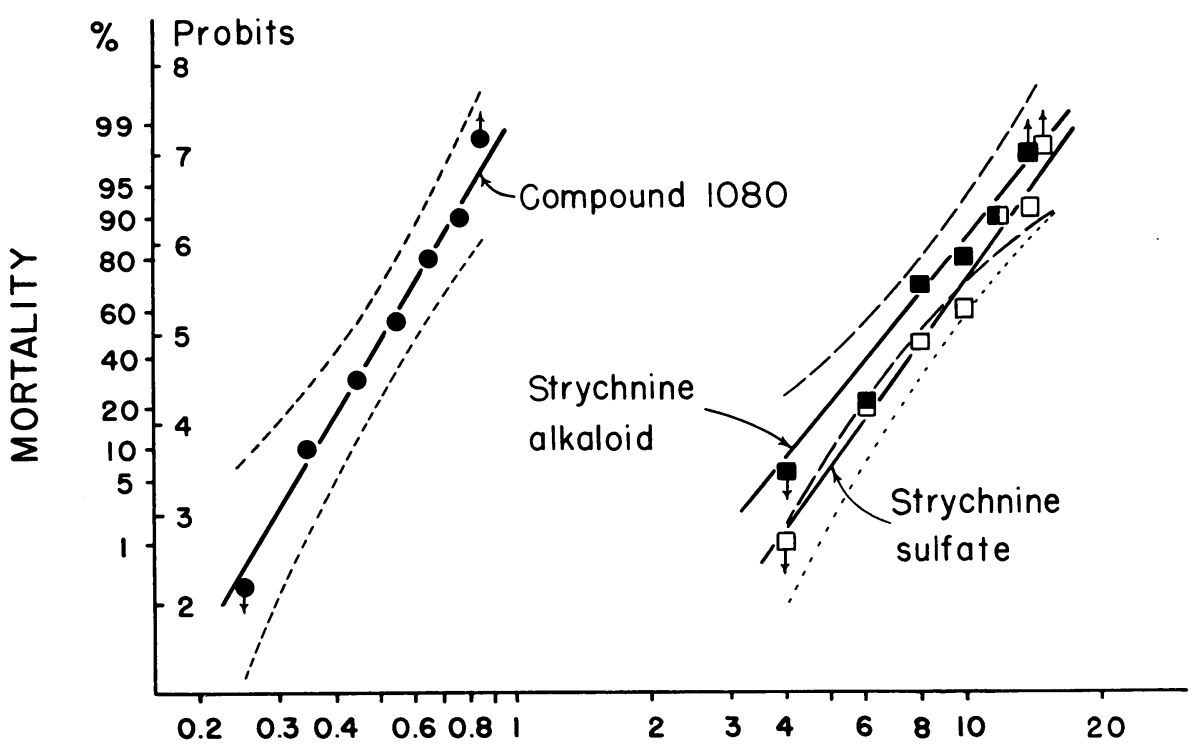

\section{DOSAGE Milligrams per kilogram}

Fig. 4. Dosage-mortality regressions computed from laboratory tests in which captive gophers were fed carrot cubes containing graded dosages of Compound 1080 (filled circles), strychnine alkaloid (filled squares), and strychnine sulfate (open squares). Data points with arrows pointing down or up represent "working probits" for zero or 100 per cent kills, respectively, which have no empirical probit equivalent. Mortality given both in probit units and in percentage of gophers killed; dosages plotted logarithmically. Dashed and dotted lines represent fiducial limits ( 5 per cent level) for strychnine alkaloid and strychnine sulfate, respectively (for clarity, the upper limit for the latter was omitted, but its position may be visualized as the mirror-image counterpart of the lower limit equidistant above the regression line for strychnine sulfate).

perature and then stored in a refrigerator. Meanwhile, standard solutions of the poisons were prepared by dissolving carefully weighed amounts of Compound 1080 and strychnine sulfate in water and of strychnine alkaloid in $0.05 \mathrm{~N} \mathrm{HCl}$. Before testing, measured amounts of the poison solutions, appropriately diluted to give the desired dosage, were added to the prepared carrot cubes by carefully pipetting $0.1 \mathrm{ml}$ of solution into the bored hole of the dried, refrigerated bait. The carrot cubes completely absorbed the solutions in 12 hours or less and were then ready for use. While absorbing the poison, the cubes were suspended freely by fine wire in vials so that none of the solution could be lost. 
Preliminary experiments were made with larger-sized poisoned baits (cylinders $5 / 8$ inch in diameter by $3 / 4$ inch in length), but in a few instances these were not entirely eaten by the test animals, and hence the dosage of poison ingested could not be accurately determined. The small baits proved satisfactory, always being completely and quickly consumed. In some early trials, the dry poison was inserted into baits, but this procedure was discarded because of the difficulty of weighing minute dosages with the desired degree of accuracy.

Gophers for bioassays were live-trapped and kept for several days before testing in individual dirt-filled cages with food and water. On test days, animals were removed to clean metal cages and deprived of food for 5 hours before being fed the poisoned cubes. Weight, sex, and other pertinent biological data were recorded, as well as kind and amount of poison administered, test conditions, symptoms, and survival times. As soon as the gopher ate its bait it was put back into the original cage and observed periodically until it died, or survived for several days with cessation of symptoms. With each experiment, one or more control animals were fed unpoisoned bait. Surviving experimental animals were later killed and autopsied.

Results of the laboratory tests and analyses of the data are given in tables 6 and 7 and figure 4. As in field tests, the superior toxicity of Compound 1080 in comparison with the strychnines is clearly demonstrated by laboratory bioassay. With an LD-50 of only $0.53 \mathrm{mg}$ per $\mathrm{kg}$ (or $0.06 \mathrm{mg}$ per gopher), Compound 1080 is about 13 times as toxic as strychnine alkaloid and about 16 times as toxic as strychnine sulfate at the same mortality level. At higher dosages, the relative potencies of these poisons are of the same order of magnitude, the ratios of equally effective dosages of Compound 1080: strychnine alkaloid:strychnine sulfate at LD-85 being 1:15:17.

Dosages of Compound 1080 found lethal to Thomomys bottae navus are somewhat higher than the values obtained by Ward and Spencer (1947) for two species of Geomys, another genus of gopher. They report an LD-100 (for Compound 1080) of $0.05 \mathrm{mg} / \mathrm{kg}$ for $G$. breviceps from Texas (9 specimens injected intraperitoneally), and an LD-100 of $0.5 \mathrm{mg} / \mathrm{kg}$ for G. floridanus, with a 60 per cent kill at $0.25 \mathrm{mg} / \mathrm{kg}$ ( 26 specimens given poison by stomach tube). No comparisons can be made between lethal-dosage determinations of strychnine for pocket gophers because the dosages here given for T. b. navus are apparently the first to be published. These values, however, are essentially in line with the highly variable lethal dosages reported for other field rodents such as ground squirrels.

The laboratory bioassay confirms the suspicion aroused in field tests that strychnine alkaloid is more potent than strychnine sulfate. At LD-50, the alkaloid form of strychnine was 1.2 times as toxic as the sulfate, the difference between their LD-50s $(1.4 \pm 0.71 \mathrm{mg} / \mathrm{kg})$ being just on the borderline of statistical significance at the 5 per cent level. At LD-85, however, the ratio of equally effective dosages of sulfate-alkaloid decreases to 1.1, and the difference between them is not statistically significant. Nevertheless, data points for sulfate fall consistently below the corresponding points for alkaloid and below the probit line for alkaloid (fig. 4), the same systematic deviation observed in plotting field-kill data (fig. 3) for the two forms of strychnine. 


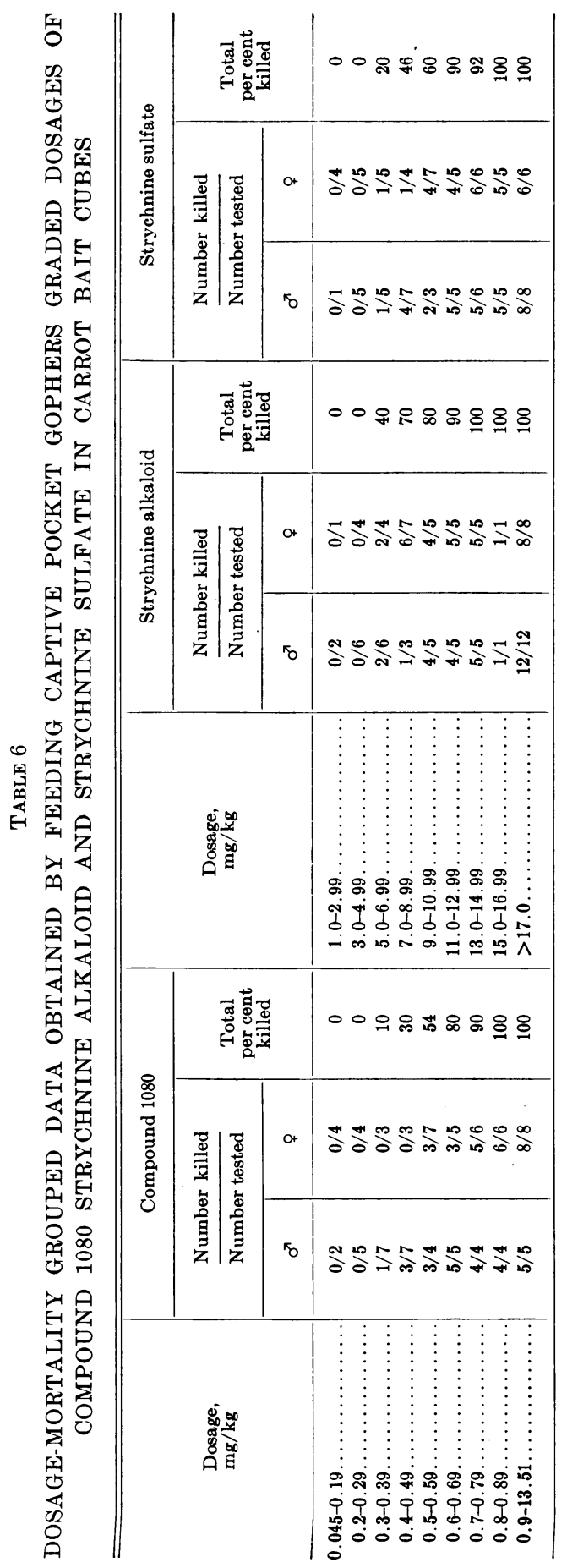


This correlation between field and laboratory tests would seem sufficient proof that strychnine alkaloid is more toxic to gophers than strychnine sulfate.

Comparison of laboratory and field lethal-dosage determinations is now pertinent to establish practical dosages of poisons for pocket-gopher control. As a basis for such comparisons, however, it is necessary to convert LD determinations from milligrams per kilogram to milligrams per gopher, since FLD determinations are computed in milligrams per burrow-assumed to be roughly equivalent to milligrams per gopher. Comparable data are given in table 8.

\section{TABLE 7}

DOSAGE-MORTALITY PARAMETERS AND LETHAL-DOSAGE ESTIMATES FOR COMPOUND 1080, STRYCHNINE ALKALOID, AND STRYCHNINE SULFATE BASED ON LABORATORY TESTS

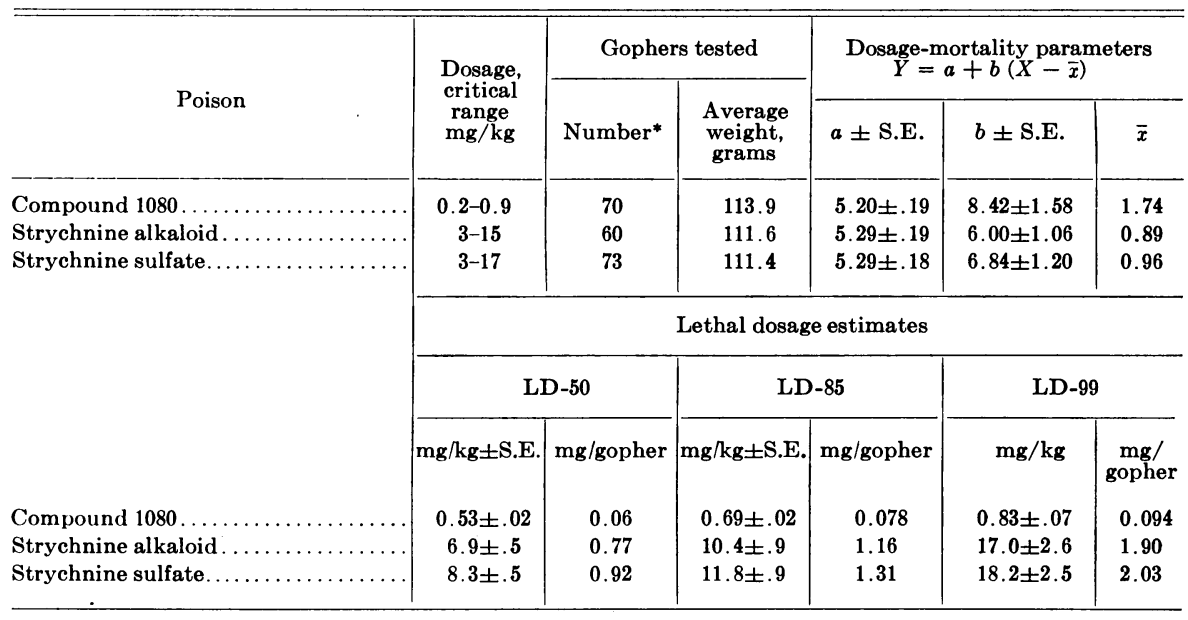

* Equal numbers of males and females tested with each poison.

It is immediately apparent that dosages required for a given percentage of kill in the field are much larger than for the same kill in the laboratory, especially for high kills. Even with such a potent poison as Compound 1080, for example, it takes 5 times as much poison to kill 50 per cent of gophers in the field as in the laboratory; and for an 85 per cent kill, 212 times as much. Factors other than toxicity are extremely important in the field performance of poison baits, especially acceptance. Leaching of soluble poisons like Compound 1080 from baits into moist soil might account for some loss in potency. Laboratory lethal-dosage determinations, therefore, are only slightly useful in establishing practical dosages of poison, since they merely evaluate toxicity. Critical field testing with graded dosages of poison on standard baits is far the better method, since the field-kills obtained are the result of all the factors involved including acceptance and toxicity.

Recommended dosages. Table 9 gives recommendations as to practical field dosages, amount of bait, and mixing proportions based principally on results of field tests. In selecting field dosages, consideration was given to the fact that the highest field-kills obtained ranged between 80 and 90 per cent, and 
that kills tend to fall off at excessive dosages. For each formulation, dosagemortality curves (fig. 3) show that there is a limit beyond which large increases in dosage yield but little additional field-kill. The tabulated dosages give practical kills with reasonable amounts of poison and represent limits beyond which it is inadvisable to add more poison. Since complete kills are rarely obtained in large-scale operations, it is better to repeat treatments to eliminate survivors of the first application than to overload the baits with poison in a vain attempt to kill all gophers with one treatment.

\section{TABLE 8}

COMPARISONS OF LETHAL DOSAGES FOR POCKET GOPHERS ESTIMATED FROM LABORATORY BIOASSAY (LD) AND FIELD TESTS (FLD)

\begin{tabular}{c|c|c|c|c|c|c}
\hline \hline \multirow{2}{*}{ Poison } & \multicolumn{3}{|c|}{50 per cent kill } & \multicolumn{3}{c}{85 per cent kill } \\
\cline { 2 - 6 } & $\begin{array}{c}\text { LD-50, } \\
\text { mg/gopher }\end{array}$ & $\begin{array}{c}\text { FLD-50, } \\
\text { mg/burrow }\end{array}$ & $\begin{array}{c}\text { Ratio } \\
\text { LD-50: FLD-50 }\end{array}$ & $\begin{array}{c}\text { LD-85, } \\
\text { mg/gopher }\end{array}$ & $\begin{array}{c}\text { FLD-85, } \\
\text { mg/burrow }\end{array}$ & $\begin{array}{c}\text { Ratio } \\
\text { LD-85 FLD-85 }\end{array}$ \\
\hline Compound 1080.......... & 0.06 & 0.3 & $1: 5$ & 0.08 & 17 & $1: 212$ \\
Strychnine alkaloid....... & 0.77 & 10.3 & $1: 13$ & 1.16 & 76 & $1: 66$ \\
Strychnine sulfate......... & 0.92 & 13.3 & $1: 14$ & 1.31 & 229 & $1: 175$ \\
\hline
\end{tabular}

TABLE 9

RECOMMENDED BAITS, DOSAGES, AND MIXES FOR POISONING POCKET GOPHERS

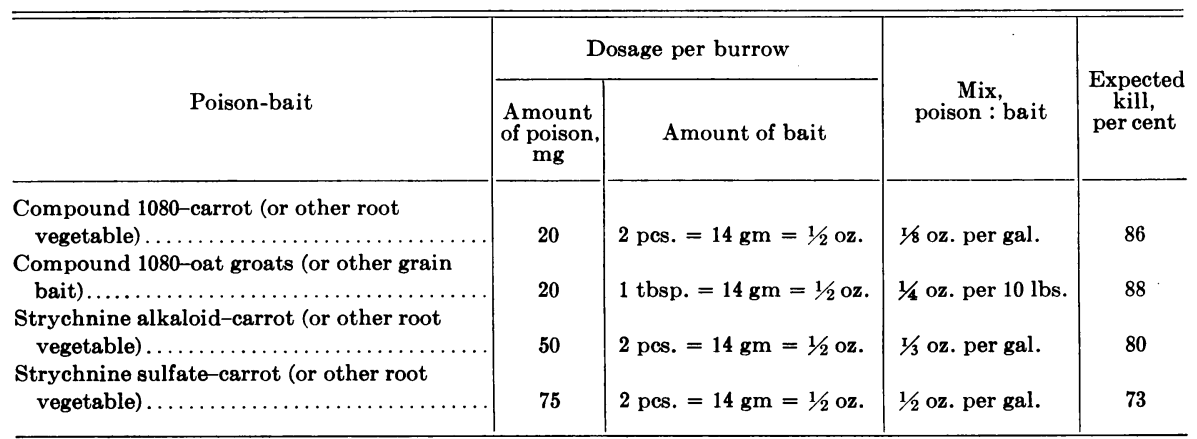

With strychnine it has been shown that the right bait must be used, but with Compound 1080 apparently any kind of bait will do. Furthermore, within practical limits, the amount, number of pieces, or size of bait is immaterial provided the dosage is kept constant and the baits are not overloaded with poison. The amount of bait here suggested is more or less arbitrary and may be modified to suit the operator's convenience. At least two pieces per burrow are recommended as a possible means of poisoning additional gophers, should more than one be present in a tunnel system.

For convenience in mixing baits, dosages were converted from metric to English and U. S. Standard equivalents and given for large batches. Bait mixes of root vegetables are based on an average of 360 pieces of cut bait per gallon (enough to treat 180 burrows), each piece measuring roughly 
$11 / 2 \times 1 / 2 \times 1 / 2$ inches and weighing about $1 / 4$ ounce (7 grams). A 10 -pound batch of Compound 1080-grain bait at 1 tablespoon per burrow will treat 324 burrows.

The $1 / 3$ ounce of strychnine alkaloid per gallon of cut vegetables (roughly equivalent to $50 \mathrm{mg}$ of poison per burrow) is a little higher dosage than the $1 / 4$ ounce of strychnine per gallon of bait (about $38 \mathrm{mg}$ of poison per burrow) commonly recommended in control bulletins, but the predicted increase in field-kill from 75 to 80 per cent perhaps justifies the increased dosage. The $75 \mathrm{mg}$ per burrow dosage for strychnine sulfate-carrot or similar baits, roughly equivalent to $1 / 2$ ounce per gallon, is double the prevailing recommendation, which is the same as for strychnine alkaloid. According to tests based on 186 burrows treated with graded dosages of strychnine sulfate bait, the $1 / 4$ ounce per gallon dosage of this poison would give only an estimated field-kill of 62 per cent, and even the $1 / 3$ ounce per gallon dosage here recommended for strychnine alkaloid would give only 67 per cent field-kill with strychnine sulfate. Since these values are too low for practical control, higher dosages of the sulfate are indicated. Certainly in view of the consistently lower kills, both in field and laboratory, produced by strychnine sulfate as compared with strychnine alkaloid, it would seem highly illogical to recommend the same dosage for these two forms of strychnine.

\section{Seasonal Effects and Related Factors}

In the preceding sections, data for the various poisons and baits were combined and tabulated regardless of the season of year in which the tests were made, since preliminary inspection indicated no obvious seasonal discrepancies. It is now pertinent to analyze the field-test data more critically on a seasonal basis.

With few exceptions, seasonal differences in field kill with any given formula were small and well within the experimental error (table 10). Significant differences were observed in only two instances: With strychnine alkaloid on carrot bait at a dosage of $40 \mathrm{mg}$ per burrow, field-kills in summer were $86 \pm 6.4$ per cent, as compared to $61 \pm 4.6$ per cent-a significant difference of 25 per cent; and with Compound 1080 on carrot, at $20 \mathrm{mg}$ dosage, fieldkills in spring were $95 \pm 4.6$ per cent, or 30 per cent higher than in winter. These differences are inconsistent, since at other dosages the same baits gave kills in winter comparable to those in other seasons. Otherwise no association between kill and season can be demonstrated, and combining data for all seasons on a yearly basis seemed justified.

Practically all tests were conducted in alfalfa fields irrigated periodically during the dry season, so that the soil was kept moist and the vegetation green throughout the year. Under these fairly uniform conditions, less seasonal variation in bait efficiency would be expected a priori than under the normal half-year alternation of wet and dry soil conditions characteristic of most of California. Incidentally, poison-bait trials in alfalfa fields presumably provide a rigorous test since baits must compete for acceptance with alfalfa - a favorite food of gophers, judging from their large populations in untreated fields of this plant. 
To test the effect of crop cover (a factor related to season of year) on bait efficiency, comparisons should be made between tests in irrigated alfalfa fields and those in nonirrigated fields during the dry season, but it is almost impossible to probe successfully for gopher runways in hard, dry ground. The few data available for such comparison were obtained in tests conducted

TABLE 10

SEASONAL ANALYSIS OF FIELD-KILLS WITH VARIOUS POISON BAITS

\begin{tabular}{|c|c|c|c|c|c|c|}
\hline \multirow{2}{*}{ Poison-bait } & \multirow{2}{*}{$\begin{array}{c}\text { Dosage, } \\
\mathrm{mg} / \text { burrow }\end{array}$} & \multicolumn{5}{|c|}{ Field-kill percentage \pm S.E. } \\
\hline & & Spring & Summer & Fall & Winter & Year \\
\hline Strychnine alkaloid-carrot......... & $\begin{array}{l}50 \\
40 \\
20\end{array}$ & $\begin{array}{c}90 \pm 4.8 \\
\ldots \ldots \\
\ldots \ldots\end{array}$ & $\begin{array}{l}80 \pm 8.0 \\
86 \pm 6.4 \\
68 \pm 7.5\end{array}$ & $\begin{array}{c}75 \pm 5.9 \\
\cdots \ldots \\
70 \pm 14\end{array}$ & $\begin{array}{l}77 \pm 6.4 \\
61 \pm 8.8 \\
57 \pm 19\end{array}$ & $\begin{array}{l}80 \pm 3.1 \\
73 \pm 5.7 \\
67 \pm 6.3\end{array}$ \\
\hline $\begin{array}{l}\text { Strychnine alkaloid-cut root vege- } \\
\text { tables (including carrots) .......... }\end{array}$ & $\begin{array}{l}50 \\
40 \\
20 \\
10\end{array}$ & $\begin{array}{c}73 \pm 5.3 \\
\ldots \ldots \ldots \\
\ldots \ldots \\
\ldots \ldots \ldots\end{array}$ & $\begin{array}{l}73 \pm 5.4 \\
77 \pm 5.7 \\
70 \pm 4.8 \\
50 \pm 12\end{array}$ & $\begin{array}{l}74 \pm 4.6 \\
68 \pm 9.9 \\
78 \pm 7.3 \\
55 \pm 15\end{array}$ & $\begin{array}{l}77 \pm 6.4 \\
61 \pm 8.1 \\
56 \pm 16 \\
38 \pm 17\end{array}$ & $\begin{array}{l}74 \pm 2.7 \\
70 \pm 4.3 \\
71 \pm 3.9 \\
48 \pm 8.4\end{array}$ \\
\hline Strychnine alkaloid-prune (soaked)... & 50 & $\ldots \ldots$ & $\ldots \ldots$ & $75 \pm 6.8$ & $75 \pm 11$ & $75 \pm 5.8$ \\
\hline Strychnine alkaloid-oat groats...... & 50 & $47 \pm 8.2$ & $\ldots \ldots+$ & & $40 \pm 6.7$ & $43 \pm 5.2$ \\
\hline Strychnine sulfate-carrot.. & 50 & $79 \pm 7.5$ & $\ldots \ldots$ & $74 \pm 8.4$ & & $77 \pm 5.6$ \\
\hline Compound 1080-carrot. & $\begin{array}{l}20 \\
5 \\
2.5\end{array}$ & $\begin{array}{l}95 \pm 4.6 \\
72 \pm 10 \\
\ldots \ldots\end{array}$ & $\begin{array}{l}\ldots \ldots \\
\ldots \ldots \\
\ldots \ldots\end{array}$ & $\begin{array}{l}\ldots \ldots \\
\ldots \ldots \\
88 \pm 7.8\end{array}$ & $\begin{array}{l}65 \pm 9.3 \\
82 \pm 9.3 \\
88 \pm 8.1\end{array}$ & $\begin{array}{l}79 \pm 5.8 \\
80 \pm 5.9 \\
86 \pm 5.8\end{array}$ \\
\hline
\end{tabular}

TABLE 11

COMPARATIVE EFFECTIVENESS OF STRYCHNINE ALKALOID-CARROT BAITS (AT 50 MG PER BURROW) IN IRRIGATED $V S$ NON-IRRIGATED FIELDS; TESTS DURING MARCH TO JUNE

\begin{tabular}{|c|c|c|c|}
\hline Crop cover & $\begin{array}{l}\text { Number } \\
\text { of gophers } \\
\text { baited }\end{array}$ & $\begin{array}{c}\text { Bait } \\
\text { acceptance, } \\
\text { per cent }\end{array}$ & $\underset{\text { percentage } \pm \text { S.E. }}{\text { Field-kill }}$ \\
\hline 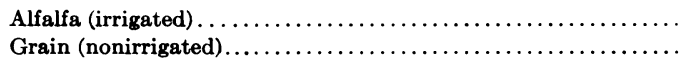 & $\begin{array}{l}25 \\
23\end{array}$ & $\begin{array}{r}100 \\
91\end{array}$ & $\begin{array}{l}92 \pm 5.4 \\
87 \pm 7.0\end{array}$ \\
\hline
\end{tabular}

during the spring (table 11). In these tests, only small insignificant differences were found in bait acceptance or field kill between the two types of field. Despite the competition of an abundant supply of fresh, green alfalfa, strychnine-carrot bait proved as effective in alfalfa fields as in green fields, if not more so.

It may be assumed, therefore, that season of year, crop cover, and other related variables have no significant influence on efficiency of poison baits for pocket gophers and, for practical purposes, can be disregarded. Poisoning of gophers may thus be carried on effectively at any convenient time of year. Obviously the best time for pest control is before rather than after the breeding season, and when field conditions are favorable for operations. 
On dry lands, gopher breeding is restricted to the spring, but in irrigated alfalfa fields of the Sacramento Valley and probably elsewhere, gophers breed throughout the year with peak periods in early winter, spring, and summer (Miller, 1946). Conditions favorable for gopher control occur during the rainy season, when the soil is moist for probing and gophers burrow actively, producing abundant, fresh mounds - a great aid in locating open tunnels (Miller, 1948). Late fall, shortly after the first heavy rains and preceding the early winter and spring peaks in breeding, is an especially favorable season for control since gophers then renew burrowing activity ; vegetational cover is low so that mounds can be seen easily; the soil is moist; and this is a slack period for agricultural labor divertible to gopher control. In irrigated alfalfa fields, June is another favorable time preceding the summer breeding peak.

\section{Lures}

Addition of various flavors, odors, and even colors to poison baits has been suggested to attract gophers or to disguise the taste of the poison. A few field experiments were made to evaluate critically the effect of adding lures to pocket-gopher baits, and to compare sweetened with unsweetened baits, and baits to which oil of anise was added with baits lacking this supposed attractant. No comparative trials were made with colored versus uncolored baits because, as mentioned above, rodents are color-blind (Walls, 1942), and coloration would not affect acceptance of baits placed in dark underground tunnels. For tests with sweetened and odorized baits, poor, medium, and fairly good formulations were purposely selected to determine whether or not their field performance could be improved by the addition of lures. It was thought that strychnine-coated grain baits would provide one of the best tests because only mediocre kills were previously obtained with this formulation.

The test data (table 12) show no significant improvement in acceptance or field-kill from addition of sugar or anise oil to any of the formulations tried. Comparison of acceptance percentages between toxic formulations in general and nontoxic controls (tables 1 to 3 and 12) indicates that the presence of poison on baits may have an appreciable repellent effect, especially at high dosages, but sweetening or adding an aromatic oil to toxic baits apparently does not overcome this difficulty. Additional experiments with other lures are needed before the question can be conclusively settled. Results thus far indicate, however, that lures can be omitted from pocket-gopher baits. The natural curiosity of the gopher toward bait materials dropped into its burrow makes other attractants seem unnecessary.

\section{Storage of Baits}

A disadvantage of cut-vegetable baits is that they spoil if not used soon after preparation, unless kept reasonably fresh by cold storage. To test the effect of such storage, a large quantity of carrot bait was prepared; half was dusted with strychnine alkaloid at $25 \mathrm{mg}$ per standard bait, and the remainder left unpoisoned. The two lots were then stored separately in covered glass jars in a refrigerator at about 35 to $40^{\circ} \mathrm{F}$. After three weeks of cold storage, 
samples of both were field-tested, the clean baits being dusted before use with strychnine alkaloid at the same dosage level as those poisoned before storage. As an experimental control, freshly prepared strychnine alkaloidcarrot baits were tested along with the stored bait. The sampling and test-

TABI,F 12

TESTS ON IUURES AIDEI) TO POISON BAITS FOR POCKET GOPHERS

\begin{tabular}{|c|c|c|c|c|c|}
\hline Poison-bait & $\begin{array}{l}\text { Dossage } \\
\text { of poison. } \\
\text { mg/burrow }\end{array}$ & $\begin{array}{l}\text { Lure, } \\
\text { substance, amount added }\end{array}$ & $\begin{array}{c}\text { Number } \\
\text { of } \\
\text { burrows } \\
\text { baited }\end{array}$ & $\begin{array}{c}\text { Bait } \\
\text { accept - } \\
\text { ance. } \\
\text { per cent }\end{array}$ & $\begin{array}{l}\text { Field-kill } \\
\text { percentage } \\
\pm \text { S.E. }\end{array}$ \\
\hline Arsenic trioxide-carrot. . . . & 200 & Cane sugar, $50 \mathrm{mg} / \mathrm{pc}$. & 50 & 92 & $10 \pm 4.2$ \\
\hline Ansenic trioxide-carrot .... & 200 & None (toxic control). & 46 & 97 & $9 \pm 4.1$ \\
\hline Strychnine alkaloid-carrot. & 40 & Cane sugar, $50 \mathrm{mg} / \mathrm{pc}$. & 25 & 85 & $60 \pm 9.1$ \\
\hline Strychnine alkaloid-carrot. . & 40 & None (toxic control). & 19 & 92 & $53 \pm 12$ \\
\hline Strychnine alkaloid-oat groatc ${ }^{*}$ & 50 & A nise oil, $0.05 \mathrm{cc} / 7 \mathrm{gm}$. & 37 & 81 & $49 \pm 8.1$ \\
\hline Strychnine alkaloid-oat groats" & 50 & None (toxic control)..... & 38 & 80 & $47 \div 8.2$ \\
\hline Oat groats (unpoisoned) & . & Anise oil, $0.05 \mathrm{cc} / 7 \mathrm{gm} \ldots$ & 8 & 100 & 0 \\
\hline Oat groats (unpoisoned) $\bullet \ldots$ & .. & None (nontoxic control).. & 8 & 100 & 0 \\
\hline
\end{tabular}

- Tests conducted by William J. Marcus under author's supervision.

TABLE 13

EFFECT OF S'TORAGE ON BAIT EFFICIFNCY

Standard 7 -gm carrot haits, each with $25 \mathrm{mg}$ strychnine alkaloid. Dosage, 2 baits per burrow.

\begin{tabular}{|c|c|c|c|c|}
\hline Storage & & & 1 & \\
\hline Storage period & $\begin{array}{l}\text { Condition } \\
\text { of bait } \\
\text { during } \\
\text { storage }\end{array}$ & $\begin{array}{l}\text { Number } \\
\text { of burrows } \\
\text { tested }\end{array}$ & $\begin{array}{l}\text { Bait } \\
\text { acceptance, } \\
\text { per cent }\end{array}$ & $\begin{array}{l}\text { Field-kill } \\
\text { wercentage } \\
\text { 土S.F. }\end{array}$ \\
\hline 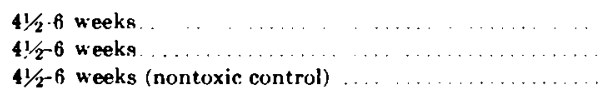 & $\begin{array}{l}\text { Poisoned } \\
\text { Clean } \\
\text { Clean }\end{array}$ & $\begin{array}{r}19 \\
20 \\
5\end{array}$ & $\begin{array}{r}95 \\
88 \\
100\end{array}$ & $\begin{array}{l}79 \pm 9.3 \\
80 \pm 8.9 \\
0\end{array}$ \\
\hline $\begin{array}{r}17 \text { weeks } \ldots \ldots \\
0 \text { weeks (toxic control) } \ldots \ldots\end{array}$ & Clean* & $\begin{array}{l}32 \\
21\end{array}$ & $\begin{array}{l}97 \\
93\end{array}$ & $\begin{array}{l}75 \pm 7.7 \\
86 \pm 7.6\end{array}$ \\
\hline
\end{tabular}

- Separate test from preceding.

ing procedure was repeated after $41 / 2$ to 6 weeks, and again after 11 weeks of storage. In a separate test, clean carrot baits were kept in cold storage for four months before being poisoned and tested. For a nontoxic control, five burrows were baited with clean carrot bait that had been in cold storage six weeks. Experimental schedules and results are summarized in table 13.

The experiments show that cut carrot baits may be refrigerated for at least six weeks without loss of effectiveness in the field, and that it makes no difference whether they are poisoned with strychnine before or after 
storage. In one experiment, both poisoned and clean baits apparently deteriorated during six to eleven weeks of cold storage, so that field-kills dropped from an 80 per cent level at six weeks to about half that at eleven weeks. In another experiment, however, clean carrot baits were cold-stored for 17 weeks at near freezing temperature, without significant loss of potency when poisoned with strychnine and tested in the field.

Conditions of refrigeration in these experiments were not rigidly controlled. The cold compartment was used for other purposes, and temperatures doubtless fluctuated considerably during the storage period. In many instances baits were coated with ice, and clean stored baits had to be defrosted and dried before being dusted with strychnine. These variations in storage conditions might explain the above-mentioned discrepancy in results. Such variations are not desirable in critical experiments, but they might occur under practical operating conditions, and the experiments are at least indicative of what might happen.

\section{Cost of Poisoning}

The cost of poisoning is difficult to estimate because of variable factors such as size of the gopher population, degree of control desired, price and availability of materials, labor costs, and operating conditions. An idea of the expense may be had by calculating for a typical operation, such as eradicating or reducing to a negligible minimum 100 gophers in a 5-acre alfalfa field (a moderate infestation) by poisoning with Compound 1080-carrot or strychnine alkaloid-carrot bait at recommended dosages.

The cost analysis given in table 14 is based on two rounds of treatment with poisoned-carrot bait, the second to eliminate survivors or gophers missed by the first application. Theoretically, two treatments with the baits used should give better than 95 per cent field kill-80 per cent $+(80 \times 20$ per cent $)=96$ per cent with strychnine alkaloid and 86 per cent $+(86 \times$ 14 per cent) $=98$ per cent with Compound 1080-carrot-assuming baits would have the same potency on second application as the first. If complete eradication is desired, traps or a different bait are preferable for any gophers surviving two rounds of poisoning, since they may be "wise" to the original treatment. For present purposes, the final few gophers may be disregarded.

With either formulation, the cost of material is nominal, amounting to three mills per gopher with Compound 1080, and about twice that with the less potent yet more expensive strychnine alkaloid. However, if culled or unmarketable carrots are used that are otherwise worthless, the cost of materials could be reduced by about $1 / 4$ cent per gopher. Such discarded vegetables are often available, and if not spoiled are usually perfectly satisfactory as gopher bait. Considerable waste is involved in cutting root-vegetable bait, here estimated as 25 per cent, and this adds to the cost of materials. Rind or peelings are generally removed because dusted poisons do not adhere to these so readily as to moist cut surfaces; stringy ends, lateral roots, and spoiled or bruised spots are discarded. Furthermore, this paring eliminates the danger of transmitting nematode infection to crops by gopher baits.

Labor is the principal cost. To labor is charged the time to assemble materials, prepare baits, probe for open gopher tunnels, place baits, smooth off 
mounds so that later fresh diggings (indicating failure) may be easily located and retreated, and to clean up. In the hypothetical case, a half-hour was allowed for preparing baits, and 31/2 hours for the other procedures. Given best field conditions-abundant fresh mounds, low vegetational cover so that gopher workings can be seen readily, and moist soil for easy and efficient probing - an experienced operator can treat 20 to 40 systems per hour, taking about 2 minutes per system on the average. Labor at $\$ 1.25$ per man hour thus comes to about $\$ 1.00$ per acre, or approximately 5 cents a gopher. The

TABLE 14

ESTIMATED COST OF GOPHER CONTROL FOR A 5-ACRE ALFALFA FIELD WITH 20 GOPHERS PER ACRE

Two Treatments to Give Greater Than 95 Per Cent Kill

\begin{tabular}{|c|c|c|}
\hline Item & $\begin{array}{l}\text { Compound } 1080- \\
\text { carrot }\end{array}$ & $\begin{array}{c}\text { Strychnine alka- } \\
\text { loid-carrot }\end{array}$ \\
\hline 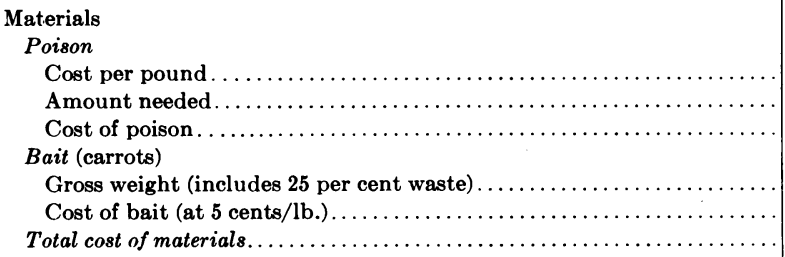 & $\begin{array}{l}\$ 12.00 \\
2.28 \mathrm{gm} \\
6 \text { cents } \\
4.69 \mathrm{lbs} . \\
24 \text { cents } \\
30 \text { cents }\end{array}$ & $\begin{array}{c}\$ 29.00 \\
6.00 \mathrm{gm} \\
38 \text { cents } \\
4.93 \mathrm{lbs} . \\
25 \text { cents } \\
63 \text { cents }\end{array}$ \\
\hline $\begin{array}{l}\text { Labor } \\
\text { Man-hours, preparing baits, field placement, etc. } \ldots \ldots \ldots \ldots \ldots \ldots \ldots \ldots \ldots \ldots \ldots \ldots \ldots \ldots \ldots \ldots \ldots \ldots \ldots \ldots \ldots \ldots \ldots \\
\text { Cost of labor (at } \$ 1.25 / \mathrm{hr} \text { ) } \ldots \ldots \ldots \ldots \ldots \ldots \ldots\end{array}$ & $\begin{array}{l}4 \text { hours } \\
\$ 5.00\end{array}$ & $\begin{array}{l}4 \text { hours } \\
\$ 5.00\end{array}$ \\
\hline 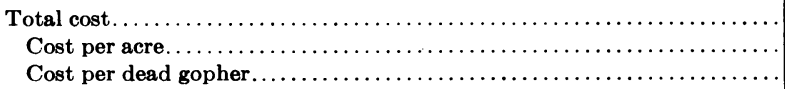 & $\begin{array}{l}\$ 5.30 \\
\$ 1.06 \\
5.4 \text { cents }\end{array}$ & $\begin{array}{l}5.63 \\
1.13 \\
5.9 \text { cents }\end{array}$ \\
\hline
\end{tabular}

cost of materials adds but 6 to 13 cents per acre (depending on the poison), or a little more than $1 / 2$ cent per dead gopher. When cost of labor is not an item, the expense of gopher control is almost negligible. To minimize labor costs, it has already been noted that the best time for poisoning is late fall or early winter, generally a slack period for agricultural labor.

The cost of controlling gophers is saved many times over by putting an end to their incessant and destructive gnawing and digging, and a few estimates will emphasize this point. The direct loss to crops destroyed by gophers (omitting other damage) has been estimated as high as 25 per cent. If the average value of an alfalfa crop is taken at $\$ 200$ per acre per year (gopherfree), just 1 per cent would more than pay for controlling an infestation of gophers that might otherwise destroy up to $\$ 50$ worth of the crop, to say nothing of the added expense incurred for irrigation water lost down gopher burrows and for repair of gopher damage to levees and ditchbanks. Indeed, the farmer can hardly afford not to control the pocket gopher. 


\section{SUMMARY AND CONCLUSIONS}

Extensive field and laboratory tests were made on the Sacramento Valley pocket gopher (Thomomys bottae navus Merriam) to determine which poisons, bait materials, and dosages are best for practical gopher control, to investigate the effect of season of year, lures, cold storage, and certain other factors on the performance of baits, and finally to estimate the cost of poisoning pocket gophers. The principal conclusions and recommendations are as follows.

1. Of nine poisons field-tested on standard bait (mainly carrot), only Compound 1080, strychnine alkaloid, and strychnine sulfate gave practical kills; Castrix and thallium sulfate were only moderately lethal; and zine phosphide, ANTU, barium carbonate, and arsenic trioxide were relatively ineffective. Compound 1080 was far superior to strychnine, and the alkaloid form of strychnine proved better than the sulfate.

Because Compound 1080 is extremely lethal to other mammals (including man) and to birds, and because there is as yet no antidote for it, its possession and use are limited by law to certain responsible and qualified persons ; it is not available to the general public.

2. All three classes of bait materials tested-namely, root vegetables, grains, and fruits-were highly effective when poisoned with Compound 1080. With strychnine, root vegetables gave the best field-kills, fruits were significantly less effective, and grains gave poor results.

3 . Within a given class of bait material, one kind was as effective or ineffective (depending on the poison used) as another.

4. Performance of proprietary poisons may be fairly predicted if their ingredients (toxic and inert) are known. Only one of four brands tested was as effective as the best experimental baits, but such large dosages of this product were needed to produce the same practical kills that for largescale control its cost would be excessive.

5. Practical field dosages for the three best poisons were established by probit analysis of field-test data as follows: for Compound 1080 with any kind of bait, $20 \mathrm{mg}$ per burrow; for strychnine alkaloid on carrot or other root vegetable, $50 \mathrm{mg}$ per burrow ; for strychnine sulfate on root vegetables $75 \mathrm{mg}$ per burrow. Using standard mixes of bait, these dosages convert to $1 / 8$ ounce of Compound 1080 per gallon of root-vegetable bait or $1 / 4$ ounce per 10 pounds of grain; $1 / 3$ ounce of strychnine alkaloid or $1 / 2$ ounce of strychnine sulfate per gallon of root-vegetable bait.

6. Field-kills tend to fall off at excessively high dosages, probably because of decreased bait acceptance.

7. Within practical limits, the amount, size, or number of pieces of bait is immaterial as long as the proper dosage of poison is conveyed to the gopher, but baits should not be overloaded with poison.

8. Dosage-mortality curves for Compound 1080, strychnine alkaloid, and strychnine sulfate were also computed by probit analysis from laboratory tests in which captive gophers were fed carrot cubes containing graded dosages of poison. From these the following LD-50's for gophers were estimated: with Compound $1080,0.53 \pm 0.02 \mathrm{mg} / \mathrm{kg}$; with strychnine alkaloid, $6.9 \pm 0.5$ 
$\mathrm{mg} / \mathrm{kg}$; and with strychnine sulfate, $8.3 \pm 0.5 \mathrm{mg} / \mathrm{kg}$. Essentially the same relative potencies of these three poisons are maintained at any level of kill.

9. Laboratory bioassay confirms the results of field tests that Compound 1080 is exceedingly potent as compared to strychnine, and that the alkaloid form of strychnine is appreciably more toxic to gophers than the sulfate.

10. For a given percentage of kill, much greater dosages are needed in the field than in the laboratory, especially for high kills, indicating that acceptance and other factors besides toxicity play an important part in the field performance of poison baits.

11. Comparison of acceptance and kill obtained at different seasons show that gopher poisoning can be carried on effectively at any time of year. The best times, however, are prior to peak breeding periods, and when field conditions are favorable, as in late autumn in California. This period is particularly. favorable because (1) it precedes winter and spring peaks in pocket-gopher reproduction, and (2) by then the first heavy rains have moistened the soil for easy probing and also stimulated burrowing activity by gophers so that active systems can be easily located by fresh mounds.

12. Sweetening gopher baits with sugar or scenting them with oil of anise did not improve acceptance or kill; therefore these flavors, odors, and similar lures can be left out of gopher-bait formulas. No tests were made with colored baits ; but since rodents in general are color-blind, and since baits are placed in dark underground tunnels, it is highly improbable that colors could attract gophers.

13. Cut carrot baits, either poisoned with strychnine or clean, may be kept in cold storage for six weeks and possibly longer without loss of effectiveness.

14. Total cost of poisoning is estimated roughly at about $5 \frac{1}{2}$ cents per dead gopher, of which about 5 cents is for labor (at $\$ 1.25$ per man hour), the remainder for materials. The cost of poisoning, especially if there is no expense for labor, is nominal as compared with the saving gained by eradicating gophers.

\section{ACKNOWLEDGMENTS}

The helpful suggestions and criticism of Professor Tracy I. Storer of the University of California at Davis, the friendly advice and encouragement of Mr. S. E. Piper, now retired from the California State Department of Agriculture, and the aid of many graduate and student assistants, including Wilbur W. Mayhew, Walter Fieg, Rufus Posey, William J. Marcus, Arthur Black, Joseph Keeler, Mrs. Shirley Wayne Downie, G. Victor Morejohn, and George Troxell are gratefully acknowledged. 


\section{LITERATURE CITED}

Buiss, C. I.

1935. The calculation of the dosage-mortality curve. Ann. Appl. Biol. 22:134-67.

BUECHNER, H. K.

1942. Interrelationships between pocket gopher and land use. Jour. Mamm. 23(3):346-48.

Соок, J. B.

1939. Pocket gophers spread Canada thistle. California Dept. Agr. Bul. 28:142-43. 2 figs.

ElLison, L.

1946. The pocket gopher in relation to soil erosion on mountain range. Ecology 27(2): 101-14. 6 figs.

Finney, D. J.

1947. Probit analysis. vi-xiii +256 p. 23 figs. Cambridge Univ. Press.

FiTCH, H. S., and J. R. BeNTLEY

1949. Use of California annual-plant forage by range rodents. Ecology 30(3):306-21. 5 figs.

GRINNELL, J.

1923. The burrowing rodents of California as agents in soil formation. Jour. Mamm. $4(3): 137-49.3$ pls.

HORN, E. E.

1923. Some notes concerning the breeding habits of Thomomys townsendi, observed near Vale, Malheur County, Oregon, during the spring of 1921. Jour. Mamm. 4:37-39. $7 \mathrm{pl}$.

HOW ARD, W. E.

1953. Tests of pocket gophers gnawing electric cables. Jour. Wildlife Management. (In press.)

KaLmbaCh, E. R.

1945. "Ten eighty," a war-produced rodenticide. Science 102:232-33.

LiTChField, J. T., and J. W. FERTIG

1941. On a graphic solution of the dosage-effect curve. Johns Hopkins Hosp. Bul. 69: $276-86$.

LITCHFIELD, J. T., and F. WILCOXON

1949. A simple method of evaluating dose-effect experiments. Jour. Pharm. and Exp. Therap. 96:99-113. 2 figs.

Miller, M. A.

1946. Reproductive rates and cycles in the pocket gopher. Jour. Mamm. 27(4):335-58. 6 figs.

1948. Seasonal trends in burrowing of pocket gophers. Jour. Mamm. 29(1):38-44.

1950. Eradication of pocket gophers. Calif. Agr. 4(12):8-10. 2 figs.

Milleer, M. A., and W. E. HowARD

1951. Size of bait for pocket gopher control. Jour. Wildlife Management 15(1):62-68.

MOORE, A. W.

1943. The pocket gopher in relation to yellow pine reproduction. Jour. Mamm. 24(2): 271-72.

MOORE, A. W., and E. H. REID

1951. The Dalles pocket gopher and its influence on forage production of Oregon mountain meadowis. U. S. Dept. Agr. Cir. 884:1-36. 15 figs.

RICHTER, C. P.

1945. The development and use of alpha-napthylthiourea (ANTU) as a rat poison. Jour. Amer. Med. Assoc. 129:927-31.

STORER, T. I.

1949. Control of field rodents in California. Calif. Agr. Ext. Serv. Cir. 138:1-50. 25 figs. [Revised.] 
STORER, T. I., and MARGERY P. MANN

1946. Bibliography of rodent control. Nat. Res. Council, Insect Control Committee Report No. 182:389 pp. mimeo.

1948. Bibliography of rodent control (first supplement), and bibliography of ANTU. U. S. Public Health Service, Nat. Inst. Health, Grant-in-aid RC-273 Report No. 1:75 pp. mimeo.

SAYAMA, K., and O. BR.UNETTI

1952. The effects of sodium fluoroacetate $(1080)$ on California quail. Calif. Fish and Game 38(3) :295-300.

THomas, $\Lambda$.

1951. Decay fungi in waterf ront structures. Report of Marine Borer Conference, May 1012, 1951 , U. S. Naval Civil Engineering Research and Evaluation Laboratory, Port Hueneme, Calif., 1951 T-1 to 5 pp. mimeo.

TOURTEI.I.TTE, W. W., and J. M. CoON

1951. Treatment of fluoroacetate poisoning in mice and dogs. Jour. Pharm. and Expt. Therap. 101:82-91.

WALLS, G. I.

1942. The vertebrate eye and its adaptive radiation. Bloomfield IIIls, Mich., Cranbook Inst. Science Bul. 19:iii-xiv, 1-785 pp.

WARD, J. C., and D. A. SP'ExcER

1947. Notes on the pharmacology of sodium fluoroacetate-Compound 1080. Jour. Amer. Pharm. Assoc. 36(2):59-62. 
The journal Hilgardia is published at irregular intervals, in volumes of about 600 pages. The number of issues per volume varies.

Subscriptions are not sold. The periodical is sent as published only to libraries, or to institutions in foreign countries having publications to offer in exchange.

You may obtain a single copy of any issue free, as long as the supply lasts; please request by volume and issue number from:

\section{Publications Office \\ College of Agriculture \\ Berkeley 4, California}

The limit to nonresidents of California is 10 separate issues on a single order. A list of the issues still available will be sent on request.

In order that the information in our publications may be more intelligible, it is sometimes necessary to use trade names of products or equipment rather than complicated descriptive or chemical identifications. In so doing, it is unavoidable in some cases that similar products which are on the market under other trade names may not be cited. No endorsement of named products is intended nor is criticism implied of similar products which are not mentioned. 